\title{
EVOLUCIÓN JURÍDICA DE LA MUJER CASADA EN EL SISTEMA MATRIMONIAL ESPAÑOL DE LA ÉPOCA PRECONSTITUCIONAL.
}

\section{LEGAL EVOLUTION OF MARRIED WOMEN IN THE SPANISH MARITAL SYSTEM FROM THE PRECONSTITUTIONAL PERIOD.}

\author{
Celia Pestaña Ruiz*
}

Recibido:25/04/2016

Aceptado: 3/06/2016

\begin{abstract}
Sumario: I.- INTRODUCCIÓN. II.- BREVE RECORRIDO HISTÓRICO. DESDE EL DERECHO ROMANO A LA II REPÚBLICA. III.- LA ESTRUCTURA PATRIARCAL. IV.- LA LICENCIA MARITAL. V.- ACTOS QUE NO PODÍA REALIZAR LA MUJER CASADA. VI.- ACTOS QUE PODÍA REALIZAR LA MUJER CASADA. VII.- LA POTESTAD DOMÉSTICA: NATURALEZA JURÍDICA. VIII.- PRIMERAS REFORMAS JURÍDICAS DEL ESTATUS DE LA MUJER. IX.MODIFICACIONES LEGALES EN LA TRANSICIÓN ESPAÑOLA: LEY DE 2 DE MAYO DE 1975. X.- BIBLIOGRAFÍA.
\end{abstract}

Summary: I.- INTRODUCTION. II.- A BRIEF HISTORICAL OVERVIEW. FROM ROMAN LAW TO THE SECOND SPANISH REPUBLIC. III.- THE PATRIARCHAL STRUCTURE. IV.- THE SPANISH MARITAL LICENCE. V.- ACTS WHICH COULD NOT BE PERFORMED BY WIVES. VI.- ACTS WHICH COULD BE PERFORMED BY MARRIED WOMEN. VII.- THE SPANISH HOUSEHOLD AUTHORITY: LEGAL NATURE. VIII.- FIRST LEGAL REFORMS OF THE STATUS OF THE MARRIED WOMEN. CHANGES IN LEGISLATION IN THE SPANISH TRANSITION: LAW OF 2 MAY 1975. X-. BIBLIOGRAPHY.

Resumen: Este estudio tiene por objeto conocer la evolución jurídica de la mujer casada en el sistema matrimonial español desde mediados del siglo XX hasta la promulgación de la Constitución de 1978. El derecho civil, reflejo de las circunstancias propias de cada periodo histórico, ha marcado la condición jurídica de la esposa, así como los valores y principios que debían regir el matrimonio y la familia. Su análisis permite conocer la calidad de vida de la mujer casada, sus derechos y sus libertades. Por esta razón, en este trabajo se analiza el régimen jurídico de la mujer casada a través de figuras jurídicas y progresos normativos previos a la Constitución. Para ello, ha sido esencial la lectura pormenorizada del Código Civil en esta materia, sus modificaciones a través de diversas leyes y la opinión de la doctrina civilista.

Palabras clave: mujer casada, sistema matrimonial, capacidad jurídica, Código Civil.

Abstract: This study aims to know the legal developments of married women in the

*Becaria FPU en la Universidad de Jaén. https://doi.org/10.17561/rej.n16.a7 
Spanish marital system since the middle of the twentieth century to the promulgation of the Spanish Constitution of 1978. Civil law, as a reflection of the circumstances of each historical period, has determined married woman's legal condition, as well as the values and principles that should govern marriage and family. Their analysis provides information about the married woman's quality of life, her rights and freedoms. For this reason, this text analyses the legal regime of married women through Spanish legal figures and normative progress before the Spanish Constitution of 1978. In order to examine this question, it has been essential a careful reading of the Spanish Civil Code in this matter, its amendments through diverse laws and the doctrinal opinion.

Keywords: married woman, Spanish marital system, legal capacity, Civil Code.

\section{I.- INTRODUCCIÓN.}

El tratamiento jurídico que el derecho matrimonial ha hecho de la mujer casada ha sido, sin lugar a dudas, uno de los temas con mayores avances en nuestro ordenamiento.

Para comprender este progreso y realizar el estudio de la situación jurídica de la esposa ha sido imprescindible ampliar hacia otras miras o áreas de conocimiento, como vienen a ser el social o histórico porque, a mi entender, sólo así se logra llegar a la razón de ser de este asunto, para después poder reducirlo al núcleo de la cuestión.

La delimitación material se circunscribe al derecho de familia, pues se trata de estudiar la figura de la mujer en el sistema matrimonial español, pero únicamente aquella que se encuentra en una determinada condición jurídica, la casada. En cuanto a la delimitación temporal y espacial, desde la segunda mitad del siglo XX hasta la llegada de la Constitución de 1978 en el territorio español.

Todo el texto orbita en torno al estatus jurídico de la esposa en la época preconstitucional. El régimen franquista, el sistema androcentrista y patriarcal sitúan a la mujer en una posición de inferioridad con respecto al hombre. Esta represión es aún mayor en el matrimonio, donde imperan los principios superiores de unidad de dirección del marido y jefatura familiar. Instituciones como la licencia marital y la potestad doméstica ciñen el campo de actuación de la mujer a aquellos negocios jurídicos imprescindibles para cumplir con sus funciones en el hogar. Se destacan como cuestiones esenciales: la limitación de su capacidad jurídica, los actos que puede realizar con plena autonomía y aquellos para los que precisa licencia, así como el poder del marido en la gestión y administración de sus intereses económicos y personales. Esta situación cambiará en la transición española, mejorando la autonomía de la esposa significativamente. Para ello, son examinados los preceptos del Código y las leyes preconstitucionales de 24 de abril de 1958, 22 de julio de 1972 y 2 de mayo de 1975, ésta última con especial interés.

Sin ánimo de hacer de éste un trabajo propio del campo de la historia del derecho, se ha querido hacer eco y aproximar en estas páginas el papel impuesto por el derecho civil a las esposas para poder comprender, en palabras del profesor RODRÍGUEZ ENNES ${ }^{1}$, el

\footnotetext{
${ }^{1}$ RODRÍGUEZ ENNES, L., Prólogo de la obra: ¿Qué igualdad? El principio de igualdad formal y no discriminación por razón de sexo en el ordenamiento jurídico español, Colección de derechos humanos y filosofía del derecho, Dykinson, $1^{\circ}$ Edición, Volumen I, Madrid, 2010, p.16.
} 
"largo y tortuoso iter seguido por las mujeres en procura del reconocimiento de su igualdad”.

Se aspira, en definitiva, a hacer una labor de denuncia sobre la situación que históricamente han sufrido las esposas y que repercute aún en nuestros días, reflejando las trabas y limitaciones jurídicas. Pero también una labor de reconocimiento por los logros y mejoras que la mujer casada ha experimentado hasta el periodo constitucional. Ello se encauza a través de las mutaciones del derecho civil y la necesidad, reclamada por los acontecimientos sociales e históricos, de un nuevo derecho matrimonial y familiar que afrontase la estructura legal franquista.

\section{II.- BREVE RECORRIDO HISTÓRICO. DESDE EL DERECHO ROMANO A LA II REPÚBLICA.}

Se hace necesario recordar sumariamente la trayectoria de nuestro derecho histórico: el derecho romano, visigodo, medieval, y la alusión de creaciones legislativas como Las Partidas o Las Leyes de Toro, por su importancia y repercusión directa en el tema que nos ocupa.

En el derecho romano primitivo, sólo los hombres gozan de plena personalidad y capacidad jurídica. Actúan en el tráfico jurídico y desarrollan trabajos con trascendencia para la sociedad (oficios viriles). La mujer, en cambio, no tiene capacidad jurídica y por ende, no tiene derechos -o más bien, está bajo el derecho de otro; es alieni iuris-. Queda desterrada de la vida social externa, reservada al varón; la mujer se encuentra sub potestate. Es una sierva del cabeza de familia, que bien podía ser el padre, antes de contraer matrimonio, o el marido, una vez casada. Dentro de las dos formas de contraer nupcias, el matrimonio cum manu le impide a la mujer la posibilidad de tener su patrimonio privativo ${ }^{2}$; los bienes que la mujer obtiene in manu pasan a formar parte de la sociedad conyugal, gestionados y administrados por el pater familias ${ }^{3}$.

Sólo el matrimonio sine manu otorga a la mujer libertad para la disposición y administración de sus bienes, ya que le permite realizar actos jurídicos de todo tipo, como enajenar bienes inmuebles o contraer deudas ${ }^{4}$. La manus mariti se adquiere mediante contrato verbal (confarreatio), o compra por el marido (coemptio), ambas formas solemnes de contraer matrimonio; pero también por usucapión de la mujer de un año ininterrumpido (usurpatio). Esta forma no solemne, conocida como usus ${ }^{5}$, deja implícito la función de la mujer romana: es una cosa más dentro del hogar. Aun cuando no está sometida al poder del padre ni del marido, y logra ser sui iuris, está bajo tutela (tutela mulieris $^{6}$ ), la cual es de por vida, y atribuida por su condición de mujer.

\footnotetext{
2 SOLAZZI, S., La restituzione della dote in Diritto Romano, Città di Castello, Italia, 1899, pp. 138 y 139.

${ }^{3}$ GÓMEZ LA PLAZA, C., De los bienes parafernales, Salamanca, 1976, p.24.

${ }^{4}$ CASTÁN TOBEÑAS, J., La condición social y jurídica de la mujer. La diferenciación de los sexos en sus aspectos biológico, sociológico, ético y jurídico, Reus, Madrid, 1955, p. 119.

${ }^{5}$ MUÑOZ GARCÍA, M. J., Limitaciones a la capacidad de obrar de la mujer casada: 1505-1975, Servicio de Publicaciones, UNEX, Cáceres, 1991, p. 36, considera que "para evitar tal efecto era preciso interrumpir la convivencia y con ella la consumación del matrimonio”.

${ }^{6}$ De la lectura de SCHULZ, F., Derecho Romano Clásico, Barcelona, 1960, pp. 171 y ss; GARCÍA GARRIDO, M. J., El patrimonio de la mujer casada en el derecho civil. I. Tradición romanística,
} 
En la Roma clásica, la condición de la mujer casada mejora. Las esposas se introducen levemente en los asuntos del foro ${ }^{7}$ y participan en actividades procesales y bancarias, pese a seguir bajo el poder del marido y sujetas a él.

En el período del derecho visigodo, impregnado del derecho romano y germano, se protege a la mujer por su papel como madre y esposa y se amplía su poder dentro del hogar, siendo posible hablar de potestad doméstica. Con respecto a la etapa anterior, se produce una cierta liberalidad de la mujer: la mujer visigoda tiene capacidad jurídica. Así con todo, no llega a superarse su posición subordinada y de acatamiento, pues sigue tutelada por el cabeza de familia, como se sustrae de la lectura de las fuentes jurídicas legislativas de la época, en especial del Liber Iudiciorum y la Lex Romana Visigothorum $^{8}$.

En el sistema jurídico del medievo algunos territorios se siguieron rigiendo por la legislación del Liber, mientras que otros empezaron a crear sus propios cuerpos normativos basados en el derecho consuetudinario, como fueron el Fuero Viejo de Castilla y el Libro de los Fueros de Castilla. En estas regiones "la condición de la mujer casada -dice MUÑOZ GARCÍA ${ }^{9}$ - era igual al hombre; todos los actos jurídicos que realizaba la familia se llevaban a cabo invocando por igual al marido y a la mujer, y aún se anteponía el de la esposa cuando se trataba de sus bienes”, sobre los que tenía la titularidad, si bien seguía siendo el marido el que disponía de los mismos y los administraba. Frente a estos dos sistemas jurídicos, coexiste un tercero, el sistema jurídico de los Fueros, siendo este último el de mayor arraigo e importancia en el período altomedieval. La mujer casada requiere, como en tiempos anteriores, de la actuación de su marido para completar su limitada capacidad de obrar ${ }^{10}$, lo cual, lejos de ser un menoscabo para la mujer, como así afirman diferentes autores ${ }^{11}$, intentaba ser un sistema de protección, ya que con el matrimonio y el grupo familiar, la mujer conseguía el amparo del marido ante los peligros que se vivían en la época, principalmente la inestabilidad del poder. Progresivamente, la inseguridad desaparece y se restablece la soberanía política, lo cual incide empobreciendo su situación.

En la España del Siglo XIII, la regulación del matrimonio y la familia, y la mujer en su seno, que venía arrastrándose desde el derecho visigodo, se mantiene sin cambios y se

Barcelona, 1982, p.143, se deduce que esta institución nació con el fin de impedir la actuación de la mujer en el tráfico jurídico. Fue perdiendo fuerza hasta desaparecer en el derecho justinianeo, aunque de facto dejó de utilizarse como tal ya en el derecho romano clásico. Además, para CASTÁN TOBEÑAS, J., op. cit., p.117, la tutela y la autorización marital se basan en diferentes razones de incapacidad: mientras que la autorización marital se constituye por la posición de la mujer en la familia, la tutela se constituye por razón de su sexo.

${ }^{7}$ CASADO CANDELAS, M. J., La tutela de la mujer en Roma, Valladolid, 1972, p. 76.

${ }^{8}$ GARCÍA GALLO DE DIEGO, A., Curso de Historia del Derecho Español, Madrid, 1959, p. 86.

${ }^{9}$ MUÑOZ GARCÍA, M. J., op. cit., pp. 56 a 62, afirma constar en el Libro de los Fueros de Castilla, 197, 208, 252,254 y 262; y Fuero Viejo de Castilla V, 1, 1.

${ }^{10}$ MERCHÁN ÁLVAREZ, A., La tutela de los menores de Castilla hasta fines del siglo XV, Sevilla, 1976, p.151; aclara que no se trataba de una total incapacidad, sino de capacidad limitada. Por ejemplo, tiene plena capacidad para heredar o ser tutora, pero conforme a MUÑOZ GARCÍA, M. J., op. cit., p. 68, es incapaz para ser fiadora, vender o comprar.

${ }^{11}$ HINOJOSA, E., La condición de la mujer casada en la esfera del derecho civil: Discursos leidos ante la Real Academia de Ciencias Morales y Políticas, Madrid, 1907, p. 360, y GÓMEZ LA PLAZA, C., op.cit., p. 224. 
convierte en derecho positivo de la mano de Alfonso X en sus cuerpos normativos.

Las Partidas, obra jurídica por excelencia y piedra angular del derecho de Castilla, implantan en sus textos la debilidad del sexo ${ }^{12}$ - el varón debe gobernar a la mujer (Partida III, 2, 5) por su mejor condición (Partida IV, 23, 2)-, el régimen dotal y la licencia marital para la mayoría de actos de la vida ${ }^{13}$.

La siguiente etapa histórico-jurídica que requiere mención es la de Las Leyes de Toro. Todo el ordenamiento jurídico relativo a la mujer dentro del matrimonio se sustentará sobre estos cimientos. En concreto, las Leyes 54 a 61 regularán instituciones como la licencia marital para todos los actos de disposición de la mujer casada (Ley 56), institución que ya existía y se instaura como principio general ${ }^{14}$; la ratificación marital (Ley 58) y la licencia judicial (Ley 57 y 58), como instrumentos jurídicos que permiten suplir la autorización del marido; la contratación y comparecencia en juicio (Ley 55), que prohíbe hacer contrato alguno sin licencia; la aceptación y repudiación de la herencia (Ley 54); renuncia a los gananciales (Ley 60); y fianza y obligación mancomunada (Ley 61). El contenido de estos preceptos se mantendría en líneas generales hasta el período preconstitucional ${ }^{15}$.

No llega siquiera a interrumpirse este sistema ante uno de los acontecimientos políticos, sociales y jurídicos más importantes del ordenamiento jurídico español, la Segunda República. Su corta vigencia impidió que las mujeres pudiesen disfrutar de los derechos que se le reconocieron ${ }^{16}$. No obstante, merece ser destacada por los objetivos cumplidos, casi utópicos. Entre ellos, la proclamación del principio de igualdad conyugal $^{17}$ y la sustancial mejora de la condición jurídica de la esposa ${ }^{18}$.

\section{III.- LA ESTRUCTURA PATRIARCAL.}

Como se venía comentando, las libertades y derechos civiles adquiridos por las mujeres en el sistema republicano fueron suprimidos pocos años después de su nacimiento. El éxito del golpe de estado y la Guerra Civil española derrocaron el gobierno de la

\footnotetext{
12 GACTO FERNÁNDEZ, E., “Imbecillitas sexus”, Cuadernos de Historia del Derecho, Murcia, 2013, p. 29, explica que la formulación romana imbecillitas seu fragilitas sexus, o la simpleza y debilidad del sexo, describía esta inferioridad física y psíquica de la mujer, por la que, como ser superior en debilidad, debía estar al poder y servicio del varón, superior en dignidad.

${ }^{13}$ MUÑOZ GARCÍA, M. J., op. cit., pp. 75 a 81, apunta que la mujer casada puede llegar a ser tutora de manera excepcional (P. VI, 16, 4 y 5), comparecer en juicio, o heredar (P.VI, 3, 2). Por otra parte, es incapaz para actuar como testigo en testamento (P.VI, 1, 9) sin la licencia del marido, ni tiene la patria potestad sobre sus hijos (P. IV, 17,2; P. IV, 18,1; P.IV, 19,3).

${ }^{14}$ MUÑOZ GARCÍA, M. J., op. cit., p. 98.

${ }^{15}$ MUÑOZ GARCÍA, M. J., op. cit., p. 270.

${ }^{16}$ RUIZ FRANCO, R., ¿Eternas menores? Las mujeres en el franquismo, Biblioteca Nueva, Madrid, 2007, p. 33, recuerda la concesión del derecho al divorcio, pues en la Segunda República el matrimonio se disolvía a petición de cualquiera de los cónyuges.

17 Art. 43.1 ${ }^{\circ}$ Constitución de 1931: La familia está bajo la salvaguardia especial del Estado. El matrimonio se funda en la igualdad de derechos para ambos sexos, y podrá disolverse por mutuo disenso o a petición de cualquiera de los cónyuges, con alegación en este caso de justa causa.

18 RICOY CASAS, R. M., ¿Qué igualdad? El principio de igualdad formal y no discriminación por razón de sexo en el ordenamiento jurídico español. Colección de derechos humanos y filosofía del derecho, Dykinson, $1^{\circ}$ Edición, Volumen I, Madrid, 2010, p. 287, así lo comenta: “la segunda república permitió la transición de las mujeres de la tradicional figura de ángel del hogar a mujer moderna”.
} 
República, trastocando profundamente el ordenamiento jurídico existente hasta el momento. Los preceptos puramente igualitarios, promotores de una situación más digna y justa para la mujer, se sustituyeron por otros opresivos y restrictivos para todos, especialmente para las mujeres ${ }^{19}$.

La dictadura reintegra a la mujer en su tradicional papel en el hogar y le asigna la tarea de promover los valores franquistas patriarcales ${ }^{20}$, mediante el lema: "mujeres para Dios, para la Patria y para el hogar" 21 , que puede traducirse, a juicio de AGULLÓ DÍAZ ${ }^{22}$, como "los valores del silencio, la modestia, la obediencia y la subordinación al hombre como los ideales que la Iglesia Católica quiere trasmitir a las mujeres”.

El régimen, de corte fascista, impone una serie de mandatos ideológicos. La mujer tiene como cometido ser madre y esposa; vivir para sus hijos y su marido. Es la perfecta ama de casa, el llamado ángel del hogar, como explica VILLANUEVA LUPIÓN"23: "para ser una buena mujer, la niña, después jovencita, debía tener como máxima aspiración el matrimonio y la formación de una familia propia”; debía ser ella la que glorificase la supremacía del varón, la maternidad y la familia, en contraposición al sistema de valores que se había alcanzado años atrás ${ }^{24}$.

La vía más eficaz de fomentar estos principios era la educación, empoderando a los niños y dirigiéndolos hacia la vida pública y política. A las niñas, sin embargo, se les inculcan ideales que merman su independencia y capacidad de decisión, pues no son de igual valor cívico ${ }^{25}$ que el hombre.

La doctrina del régimen fue impulsada por la Sección Femenina de la FET y de las JONS 26 "se encargó de la educación social, política y doméstica de todas las jóvenes y

\footnotetext{
19 SENDER BEGUE, R., Luchando por la liberación de la mujer, Universidad de Valencia, Valencia, 2006, p. 182, narra que "tras la Guerra Civil, nosotras las mujeres perdimos más que los hombres, porque además de la libertad y la democracia, Franco nos arrebató todos los derechos que la Republica nos otorgó".

${ }^{20}$ MOLINA PETIT, C., Dialéctica feminista de la ilustración, Barcelona, 1994, p. 175, considera que fue Kate Millet, en torno al 1960, la creadora del término patriarcado, como definición de la estructura jerárquica en la que el hombre es superior a la mujer y ejerce sobre ella su poder.

${ }^{21}$ MADRID IZQUIERDO, J. M., El acceso de las mujeres españolas a la educación, una cuestión histórica e ideológica, Homenaje al Profesor Alfonso Capitán, Universidad de Murcia, Murcia, 2005, p. 291.

${ }^{22}$ AGUlLÓ DÍAZ, M. C., Mujeres para Dios, para la Patria y para el Hogar. (La educación de las mujeres en los años 40). Actas del IV Coloquio de Historia de la Educación mujer y Educación en España, 1868-1975, Universidad de Santiago, Santiago de Compostela, 1990, pp. 17 a 26; en MADRID IZQUIERDO, J. M., op. cit., p. 291.

23 VILLANUEVA LUPIÓN, C., "La condición jurídica de la mujer contemporánea de Carmen de Michelena. La visión de la igualdad en el horizonte.” Homenaje a Carmen de Michelena, Seminario Interdisciplinar de Estudios de Género, Universidad de Jaén, Jaén, 2014, p. 45.

${ }^{24}$ VALPUESTA FERNANDEZ, M. R., La disciplina constitucional de la familia en la experiencia

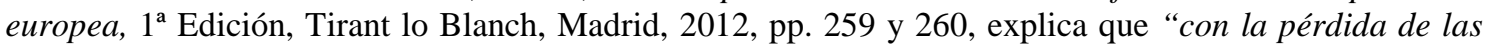
libertades en España las cosas vuelven a su cauce y la mujer al hogar, en una estructura familiar que en poco difiere de la existente antes del cambio democrático de la Segunda República”.

${ }^{25}$ REY MARTÍNEZ, F., El derecho fundamental a no ser discriminado por razón de sexo, Mcgraw-Hill, Madrid, 1995, p. 2.

${ }^{26}$ VENTURA FRANCH, A., Las mujeres y la Constitución española del 1978, Instituto de la mujer, Madrid, 1999, p. 91.
} 
mujeres a lo largo de la existencia del régimen"27. Junto con la Sección Femenina, el catolicismo velará por la moral imperante y el acatamiento de las funciones impuestas ${ }^{28}$. Por estas razones, la Iglesia y la Sección Femenina contaban con el apoyo del Estado, compartían ideología y perseguían los mismos objetivos.

De todo lo anterior, es innegable que el régimen de Franco tuvo unas consecuencias nefastas para las mujeres, una repercusión directa sobre sus derechos y capacidad jurídica que tardaría décadas en reconducirse, pues el derecho civil -como el resto de campos legislativos- fue un espejo del sistema.

\section{IV.- LA LICENCIA MARITAL.}

En la época a la que nos referimos, comenta claramente POTHIER ${ }^{29}$, la unidad que se crea del matrimonio hace que el marido asuma el mando y ejerza la jefatura familiar. La sociedad conyugal otorga "en calidad de tal un derecho de potestad sobre la persona de la mujer", que consiste "en el derecho de exigirle todos los deberes de sumisión que a un superior son debidos”. Este poder sobre la esposa, llamado potestad o licencia marital, al igual que otras instituciones, no se regula expresamente en el Código civil de 1889, aunque se deduce de diferentes preceptos.

La licencia marital nace del matrimonio, cambiando el estatus jurídico del hombre mediante la aportación de derechos, y de la mujer, restringiendo su capacidad y esfera de actuación personal y patrimonial, dado que "pierde la facultad de ejercer por sí sola la mayor parte de sus derechos civiles: el interés de la asociación conyugal y la deferencia que debe a su marido la obligan a no hacer jamás cosa importante sin su autorización "30. Esta limitación de la esposa en su capacidad jurídica se completa con la licencia que el marido le concede.

LACRUZ denomina la licencia marital como "la primera expresión de la supremacía del varón- (...) cualesquiera que sean el régimen matrimonial y el modo de administración, es el marido quien debe determinar su tenor de vida"31. Ha sido considerada como una autoridad protectora, tuitiva, que "no implica una verdadera potestad ni una prerrogativa del sexo, sino más bien una función encomendada al marido por exigencias de unidad de gobierno, y que se traduce para él en graves

\footnotetext{
27 MORAGA GARCÍA, M. A., "Notas sobre la situación jurídica de la mujer en el Franquismo”, Feminismo: revista del Centro de Estudios sobre la Mujer de la Universidad de Alicante, Alicante, 2008, p. 233.

28 CASTÁN TOBEÑAS, J., op. cit., p. 69. Además, en DI FEBO, G., "Nuevo Estado, nacionalcatolicismo y género", en NIELFA CRISTÓBAL, G., Mujeres y hombres en la España franquista, sociedad, economía, política y cultura, Instituto de Investigaciones Feministas-UCM, Madrid, 2003, p. 31.

${ }^{29}$ POTHIER, R. J., Tratado de la potestad del marido sobre la persona y bienes de la mujer, traducción de Noguera y Carles, Barcelona, (s.f.), pp.255 y 257.

${ }^{30}$ ESCRICHE, J., Diccionario razonado de legislación civil, penal, comercial y forense, o sea, resumen de las leyes, usos, prácticas y costumbres, como asimismo de las doctrinas de los jurisconsultos. Valencia, 1838, p. 426.

31 LACRUZ BERDEJO, J. L., Derecho de familia. El matrimonio y su economía, Civitas, Tratado teórico-práctico de Derecho civil, Volumen 1º, Tomo IV, Barcelona, 1963, p. 200.
} 
deberes y responsabilidades ${ }^{32}$. El marido actúa en el interés superior de la familia, recayendo sobre su persona la responsabilidad de la autoridad marital, que se cimenta precisamente sobre la unidad de dirección, sin ser esta autoridad "un mero derecho subjetivo, sino una auténtica potestad familiar"33; "no es un derecho que atribuya una preeminencia de voluntad de uno sobre la de los otros; es, en esencia, un deber por el que el titular debe ser considerado como investido de una función, o lo que es lo mismo, consecuencia de un deber preexistente e indispensable a la consecución del fin del grupo. En él no hay derechos de naturaleza individual" 34 .

De esta línea de pensamiento se extraen varias conclusiones. En primer lugar, el poder de gobernar y decidir sobre la mujer no se percibe como un privilegio para el marido, sino como una obligación o deber de actuación para el mismo. En segundo lugar, la licencia marital no protege al marido ni su esfera patrimonial, ni protege a la mujer, pues no tiene como fin beneficiar a uno de los miembros de la familia individualmente considerados, sino que preserva los intereses de la unidad familiar.

Pero las opiniones no son tan unánimes. Otro sector doctrinal consolida diversas deliberaciones, bajo mi punto de vista, más correctas, rechazando la licencia marital como mecanismo que salvaguarda la comunidad conyugal, en tanto que restringe la capacidad jurídica de la mujer en beneficio de su consorte, como argumenta DE CASTRO: la esposa "tiene limitada capacidad por una causa meramente externa, la protección de otra persona, la de su marido, y no su propia protección y de sus intereses patrimoniales" 35 . "Hoy no es la mujer la protegida, sino el marido y sus herederos” ${ }^{36}$, cuestión en la que entraremos más adelante.

Por medio de la potestad marital, el legislador inhabilitó a la esposa para desempeñar un conjunto de funciones que no le correspondían por su condición, instaurando este instrumento $^{37}$ para asegurar la supervisión del marido en todo aquello que superase la frontera del hogar.

Se mantiene la necesidad de la potestad marital para "asegurar la estabilidad y cohesión del grupo familiar por la aplicación de un moderado principio de autoridad" 38 y, seguidamente, “deben ser mantenidas en lo esencial aquellas normas que reconocen al marido, en circunstancias ordinarias, la condición de jefe de familia, de acuerdo con las aspiraciones cristianas”.

De todo lo anterior, no cabe duda de que mientras perdurase en el sistema jurídico la figura de la licencia marital, no era posible hablar de una igualdad de derechos y

\footnotetext{
${ }^{32}$ CASTÁN TOBEÑAS, J., op. cit., p. 173.

${ }^{33}$ COSSÍO Y CORRAL, A., La potestad marital, Instituto Nacional de Estudios Jurídicos, Madrid, 1948, p. 19.

34 BARATTA, V., La situación jurídica de la mujer, esposa y madre, en la familia según las distintas legislaciones. Rivista del Notariato, Nápoles, 1953, pp. 491 y ss.

${ }^{35}$ DE CASTRO Y BRAVO, F., Derecho Civil de España. Parte General, T.I, libro preliminar, Introducción al Derecho Civil, Madrid, 1949, p. 264.

36 Ídem, pp.258 y ss.

${ }^{37}$ MUÑOZ GARCÍA, M. J., op. cit., p. 98, recuerda la antigüedad de esta institución, presente incluso en las Leyes de Toro de 1505, en la que se fijó como Derecho positivo pues, ya con anterioridad, existía como derecho consuetudinario.

${ }^{38}$ CASTÁN TOBEÑAS, J., op. cit., pp. 221 y 222.
} 
obligaciones entre los cónyuges, puesto que, una vez contraídas nupcias, el estado jurídico de uno es muy diferente al del otro.

De la lectura de las obras de aquella época se observa la dificultad que suponía para la doctrina diseñar un modelo matrimonial en paridad. Aun cuando algunos de ellos rechazaban la supremacía masculina en el consorcio conyugal, para la mayoría ${ }^{39}$ era una cuestión casi utópica pensar en un matrimonio en el que no hubiese una voz predominante. De esta orientación es BARATTA ${ }^{40}$, para quien "poco importa que el poder y la función recaigan en uno u otro de los cónyuges, a los que la costumbre o la ley pueda habérselos atribuido al hombre. Lo esencial es que haya una organización unitaria y un ejercicio disciplinado de poderes limitados”.

Por ende, el matrimonio no se concibe por aquel entonces sin una autoridad, que encuentra su razón de ser, conforme a la teoría preeminente ${ }^{41}$, en el principio de la unidad de dirección. Uno de los consortes (nunca indistintamente, siempre el marido) está llamado por el derecho para regir la vida conyugal y guiar a la familia, entendida ésta como "un organismo unitario, donde sus miembros obran y deben obrar para la realización de un interés superior a aquel particular de cada uno"42. La unidad de dirección se llevará a cabo cuando no sea posible un consenso en el matrimonio, "ya que no le es lícito al marido prescindir de la iniciativa y voluntad de su mujer" "43, por lo que se empleará cuando existan diferencias. Es entonces cuando "se impone, como un mal menor y para evitar la anarquía en la familia, conservar un último vestigio de autoridad marital”.

De aquí se puede deducir lo siguiente. Por una parte, el carácter subsidiario de la jefatura familiar, acorde a lo establecido en las líneas precedentes; por otra, la prohibición que se desprende de ejercer la autoridad marital de forma caprichosa o despótica por el cabeza de familia, que pudiese menoscabar la persona o los intereses de la mujer o los hijos. Es lo que se conoce como abuso de derecho, que comprende "no solamente la opresión de la mujer, sino toda decisión contraria a la afección y al interés que el esposo debe a su consorte y que desvíe la autoridad marital del fin que la ley asigna"44. Es una conclusión lógica: el sistema jurídico otorga al varón grandes facultades, reuniendo en su persona un poder que, si bien pretende defender el interés superior familiar, del mismo modo puede ponerlo en riesgo.

En este punto, COSSÍO ${ }^{45}$ señala que "la potestad marital no ha de ser concebida ni

\footnotetext{
${ }^{39}$ Conforme a POTHIER, R. J., op. cit.; CASTÁN TOBEÑAS, J., op. cit.; BARATTA, V., op. cit.; SPENCER, H., op. cit.; entre otros.

${ }^{40}$ BARATTA, V., op. cit., pp. 491 y ss.

${ }^{41}$ CASTÁN TOBEÑAS, J., op. cit., pp. 111 a 116, señala otras teorías, como la autoridad fundamentada en la posición económica, la autoridad doméstica designada de común acuerdo, etc, las cuales no han tenido el arraigo histórico, jurídico y social del que sí ha gozado la teoría de la autoridad marital justificada por la unidad de dirección.

42 BARATTA, V., op. cit., pp. 491 y ss.

${ }^{43}$ CASTÁN TOBEÑAS, J., op. cit., p. 112.

${ }^{44}$ GRANOTIER, P., L'autorité du mari sur la personne de la femme et la doctrine féministe, Giard et Brière, París, 1909, p. 322.

${ }^{45}$ COSSÍO Y CORRAL, A., La potestad marital. Instituto Nacional de Estudios Jurídicos. Madrid, 1948, p. 33.
} 
regulada como un poder absoluto. Si la familia tiene un sentido institucional y es un organismo determinado por exigencias superiores a la voluntad y los fines de los individuos que la integran, ha de ser arbitrado el medio de impedir que los órganos rectores de la familia actúen en su propio interés y no en interés del grupo". Es por ello que "los derechos del marido han de ejercerse sin abuso ni desviación de poder". Este es el fundamento de la intervención judicial en la licencia marital, que se articula para proteger a la esposa contra la arbitrariedad y violencia de su cónyuge, "supliendo en determinados casos la autorización marital" y velando para que "dichos poderes no traspasen sus límites, legales ni morales "46.

Asimismo, la potestad marital debe ser entendida en sentido restrictivo, pudiendo la mujer en la década de los 50 y 60 "actuar jurídicamente sin licencia, siempre que la ley no exija expresamente tal requisito, interpretación de acuerdo con la conciencia jurídica actual y las nuevas tendencias legislativas" ${ }^{7}$.

La potestad marital es defendida como la única herramienta válida en el sistema jurídico para solventar los problemas que pudiesen causarse del desacuerdo entre los cónyuges, siendo conveniente que ambos tomasen decisiones en común, e incluso compatible con la atribución a la mujer de la jefatura familiar, aunque solo en situaciones de excepción.

Ante ciertas circunstancias, que pueden ser permanentes, como la declaración de ausencia del marido, interdicción civil o declaración de incapacidad del marido por locura o sordomudez; así como circunstancias temporales, como haber sido declarado en rebeldía o prófugo, la mujer tiene autoridad en la familia. En estos casos, la esposa deja de estar sometida al mando de su marido, y se amplían sus libertades relativamente, al poder administrar los bienes matrimoniales ${ }^{48}$. Se debe incidir en esa relatividad, dado que se necesita de licencia judicial para los actos de mayor importancia como, por ejemplo, para disponer de estos bienes ${ }^{49}$.

\section{La controvertida capacidad de la mujer casada.}

Dicho esto, otra cuestión importante en la que incidir es en la naturaleza jurídica de la capacidad de la mujer casada. Es aceptado por la generalidad de la doctrina ${ }^{50}$ que la

\footnotetext{
${ }^{46}$ CASTÁN TOBEÑAS, J., op. cit., pp. 147 y ss.

${ }^{47}$ COSSÍO Y CORRAL, A., La potestad...., p. 33.

48 Art. 1441 Cc de 1889: La administración de los bienes del matrimonio se transferirá a la mujer: $1 .^{\circ}$ Siempre que sea tutora de su marido, con arreglo al artículo 220. 2. ${ }^{\circ}$ Cuando pida la declaración de ausencia del mismo marido, con arreglo a los artículos 183 y $185.3^{\circ}$ En el caso del párrafo primero del artículo 1.436. Los Tribunales conferirán también la administración a la mujer, con las limitaciones que estimen convenientes, si el marido estuviere prófugo o declarado rebelde en causa criminal, o si, hallándose absolutamente impedido para la administración, no hubiere proveído sobre ella.

49 Art. 1444 Cc de 1889: La mujer no podrá enajenar ni gravar, durante el matrimonio, sin licencia judicial, los bienes inmuebles que le hayan correspondido en caso de separación, ni aquellos cuya administración se le haya transferido. La licencia se otorgará siempre que se justifique la conveniencia o necesidad de la enajenación. Cuando ésta se refiera a valores públicos, o créditos de empresas y compañías mercantiles, y no pueda aplazarse sin perjuicio grave o inminente del caudal administrado, la mujer, con intervención de agente o corredor, podrá venderlos, consignando en depósito judicial el producto, hasta que recaiga la aprobación del Juez o Tribunal competente. El agente corredor responderá siempre personalmente de que se haga la consignación o depósito a que se refiere el párrafo anterior.

${ }^{50}$ MUÑOZ GARCÍA, M. J., op. cit.; MANRESA Y NAVARRO, J. M., Comentarios al Código Civil español, T.I, Revista de Legislación, Madrid, 1945; COSSÍO Y CORRAL, A., op. cit.; CASTÁN
} 
esposa no goza de la misma posición jurídica que el marido, quien debe completar su capacidad. La discusión surge al interpretar el grado de incapacidad.

Un sector doctrinal afirma la disminución de la capacidad de obrar de la mujer, especialmente $^{51}$ al contraer nupcias, pero niega su incapacidad stricto sensu, pues no todas las mujeres gozan de la misma condición jurídica -ésta tiene una dependencia directa del estado civil- y la condición de mujer, per se, no conlleva la incapacidad. "Al ser la mujer, soltera o viuda, -explica MUÑOZ GARCÍA ${ }^{52}$ - plenamente capaz (e incluso la casada misma cuando realiza actos propios de la "potestad doméstica"), y no serlo la mujer casada, no hay incapacidad natural, no se puede basar en la imbecillitas seu fragilitas sexus, sino que hay que buscar esta limitación en otros argumentos jurídicos: en la potestad marital dentro de la sociedad conyugal y en el principio de unidad de dirección del patrimonio conyugal”.

Ahora bien, argumenta este sector que su grado de incapacidad no es equiparable a la de un menor, para el que la falta de capacidad responde a la falta de madurez psíquica, que exige de un tutor o representante legal que supla su voluntad. En el ordenamiento jurídico hasta la década de los 70, "la actividad de la mujer se limita solo en la medida en que se reputa necesaria para el mantenimiento de la armonía personal y económica de la sociedad conyugal" 53 . DE CASTRO ${ }^{54}$ apoya esta teoría: "el artículo 32Cc, con razón, no enumera la condición de la mujer casada entre las causas de restricción de la personalidad.”, lo que sí ocurre con la minoría de edad.

A mi parecer, bien es cierto que hay diferencias sustanciales entre ambas capacidades, pero estas diferencias responden a la función para la que se instituyen, y no en la mayor o menor merma que cada una produce en la autonomía. La función del representante legal del menor ejerciendo la patria potestad y la función del marido ejerciendo la potestad marital se rigen por valores diferentes, si seguimos con la línea argumental defendida por la doctrina mayoritaria. Mientras el primero buscará el bien para el menor y velará por sus intereses, el segundo no tiene por fin el interés de la esposa, sino el de la sociedad conyugal, conforme al principio de unidad de dirección.

En todo caso, LACRUZ matiza que, jurídicamente, la mujer puede asimilarse a un menor emancipado; es decir, "a una persona en principio capaz, a la que se limita la posibilidad de celebrar algunos actos concretos para los cuales necesita un complemento de capacidad"55. Efectivamente, el legislador inhabilita a la mujer para realizar ciertos negocios jurídicos - aunque no precisa el autor que para aquellos que

TOBEÑAS, J., op. cit.; entre otros. En desacuerdo está LACRUZ BERDEJO, J. L., op. cit., p. 203, obra en la que hace multitud de referencias, entre ellas: "el marido no completa ninguna supuesta incapacidad de la mujer, y por tanto, para prestar eficazmente -la licencia-, no es necesaria ninguna supuesta capacidad".

${ }^{51}$ Hago hincapié en este especialmente, pues la mujer no ha necesitado contraer matrimonio para sufrir limitaciones en su capacidad y en sus libertades, como ponen de manifiesto los art. 45 Cc y 321 Cc.

${ }^{52}$ MUÑOZ GARCÍA, M. J., op. cit., p.98. De la misma opinión, LACRUZ BERDEJO, J. L., op. cit., p. 184, "la mujer, soltera o viuda puede realizar los mismos contratos que un hombre, la casada, sigue siendo capaz en principio".

${ }^{53}$ COSSÍO Y CORRAL, A., op. cit., pp. 27 y ss; CASTÁN TOBEÑAS, J., op. cit., pp. 184 y ss.

${ }^{54}$ DE CASTRO Y BRAVO, F., Derecho Civil de España, T.II, Vol.1º, Madrid, 1952, pp. 258 y ss.

${ }^{55}$ LACRUZ BERDEJO, J. L., op. cit., p.183. 
tienen cierta relevancia-, pero puede actuar por sí misma para otros - para aquellos que quedan circunscritos al hogar-.

Otra parte de la doctrina, sin embargo, ha visto en la esposa restricciones en su capacidad más graves. Ciertamente, "es forzoso reconocer la capacidad de la mujer siempre que dejen un resquicio para ello los preceptos del Código" ${ }^{56}$, los cuales han tenido que decir, y mucho, en esta materia. La institución de la potestad marital y su necesidad de licencia es el argumento de peso utilizado por aquellos que igualan su situación jurídica a la del menor o incapaz ${ }^{57}$, pues "mutuamente se condicionan: la incapacidad de la mujer y la potestad del marido, en tanto que aquélla es la causa de extensión de ésta" ${ }^{\text {} 58}$. De hecho, la ordenación de la licencia marital se hace precisamente con el fin de completar sus limitaciones jurídicas, por lo que afirmar la capacidad de obrar supone negar la institución de la autoridad marital ${ }^{59}$, aunque al respecto también hay quien discrepa ${ }^{60}$. Acorde con este pensamiento, el art. $1263 \mathrm{Cc}^{61}$ prohibía a las mujeres casadas, al igual que a los menores no emancipados y los locos o dementes y los sordomudos que no supiesen escribir, a prestar consentimiento. Del propio Código extraemos, como opinión más acertada, que el emancipado y la mujer han tenido posiciones distintas ante la ley ${ }^{62}$, siendo la condición jurídica de la esposa inferior al menor emancipado, pues la esfera de actuación de este último es más amplia y cercana a la mayoría de edad.

\section{Características de la licencia.}

La potestad marital tuvo durante el tiempo de su vigencia una repercusión jurídica ineludible, de ahí su importancia como una de las instituciones de derecho de familia y matrimonial que mejor encarna los principios del régimen y del patriarcado, además de instaurarse como la figura jurídica por excelencia que ha ido marcando los tiempos de los sucesivos progresos y entorpeciéndolos.

Los efectos de la licencia se observan precisamente en la validez a la hora de actuar en

\footnotetext{
${ }^{56}$ CASTÁN TOBEÑAS, J., Derecho Civil, $8^{a}$ edición, T.I, Volumen 2o, Reus, Madrid, 1955, pp. 507 y ss; DE BUEN Y LOZANO, D., Notas al Curso de Derecho civil de Colin y Capitant. T. II, volumen $1^{\circ}$, Madrid, (s.f), p. 409; PÉREZ GONZÁLEZ, B., y CASTÁN TOBEÑAS, J., Notas a la edición española del Derecho de Familia de Theodor Kipp y Martin Wolf. 2ª edición, Vol. I, Barcelona, 1979, p. 207.

${ }^{57}$ MUÑOZ GARCÍA, M. J., op. cit., p. 98, expresa que "la mujer está bajo la potestad del marido por su propia condición natural de mujer, que la hacía equiparable o asimilable al menor". De la misma opinión es IMAZ ZUBIAUR, L., "Superación de la incapacidad de la mujer casada para gestionar su propio patrimonio", en Mujeres y derecho: pasado y presente, Congreso multidisciplinar de la sección de Bizkaia de la Facultad de Derecho, Universidad del País Vasco, País Vasco, 2008, p. 72, al decir: "el marido es el representante legal de la mujer, por lo que ésta queda equiparada a los menores de edad o a los incapaces".

${ }^{58}$ COSSÍO Y CORRAL, A., op. cit., p.14.

${ }^{59}$ MANRESA Y NAVARRO, J. M., op. cit., p. 383.

${ }^{60}$ LACRUZ BERDEJO, J. L., op. cit., p. 184, dice que la licencia "no es tanto como un complemento de la capacidad de obrar de un sujeto menos capaz, sino como un plus por hallarse dicho sujeto bajo la potestad personal de otro".

${ }^{61}$ Originario artículo 1263 Cc: No pueden prestar consentimiento: $1 .^{\circ}$ Los menores no emancipados. $2 .^{\circ}$ Los locos o dementes y los sordomudos que no sepan escribir. $3 .^{\circ}$ Las mujeres casadas en los casos expresados por la ley.

${ }^{62}$ GÓMEZ MORÁN, L., La mujer en la historia y en la legislación, Derecho de Familia, Reus, Madrid, 1944, p. 255; pp.370 a 371.
} 
el tráfico; es decir, en la naturaleza jurídica de los actos que realiza la mujer. Aquellos negocios que requieran la autorización del marido y se concluyan con ella, son perfectamente válidos. Estos actos deberán llevarse a cabo con "Ia diligencia propia de un padre de familia" 63 y de buena fe.

A sensu contrario, los que la mujer desempeñe sin licencia serán inválidos, es decir, "producen efectos jurídicos sin ocasionar nulidad plena ipso iure”,64, "perteneciendo esta invalidez a la denominada anulabilidad". LACRUZ incide en que "lo peculiar de esta forma de invalidez es que, no tratándose de una nulidad debida a incapacidad propiamente dicha, no puede ser convalidada por el supuesto incapaz, y si solo por la persona en cuya protección se citó la norma" 65 .

Esta es la razón por la que los actos jurídicos que se realicen sin licencia son anulables, y no nulos, porque "adolecen de un defecto de capacidad, si bien, tienen todos los requisitos legales para obligarse (consentimiento, objeto y causa)"66. Los negocios para los que la mujer no tenga capacidad podrán ser impugnados por el cónyuge, y con ello, anulados, pero mientras no sea así, ese negocio jurídico desprovisto de capacidad, será válido y surtirá efectos.

Para la anulación del acto sólo está legitimado el marido, que es la persona que ostenta la potestad marital, la cual es estrictamente personal ${ }^{67}$, lo que excluye la posibilidad de delegación para su ejercicio, sin perjuicio de que los causahabientes del mismo puedan ejercitar la acción para anular el negocio jurídico ${ }^{68}$. Del mismo modo, es revocable, "tanto por el principio de revocabilidad permanente del mandato como por su propia naturaleza"69, siendo, ahora sí, adecuadas las normas del mandato para su revocabilidad, pese a que no sea susceptible en la licencia marital el establecimiento de mandante distinto del marido. Es también irrenunciable ${ }^{70}$ e inherente a la condición de marido.

La licencia puede otorgarse expresamente, a través de documento o de forma escrita, y tácitamente, "por actos de los que se deduzca que el marido consiente el acto de la mujer": ambas formas son aceptadas y válidas. La admisión de la licencia implícita facilitará la actuación de la esposa en el tráfico jurídico, porque el mero consentimiento del marido complementará su defecto de capacidad.

De esta forma, cuando el marido consiente, bien desde un primer momento, bien $a$ posteriori ratificando su voluntad, queda el acto "subsanado por la licencia marital: ya

\footnotetext{
${ }^{63}$ MUÑOZ GARCÍA, M. J., op. cit., p. 104.

64 Ídem, p.106

${ }^{65}$ LACRUZ BERDEJO, J. L., La potestad doméstica de la mujer casada, Zaragoza, 1963, p. 216.

${ }^{66}$ MUÑOZ GARCÍA, M. J., op. cit., p. 106.

67 LACRUZ BERDEJO, J. L., op. cit., p. 204, "pues el ser marido es officium personal", e indirectamente, el carácter personalísimo se consolida en "el respeto a la autoridad que corresponde a la mujer en el matrimonio”. Así con todo, una parte minoritaria de la doctrina niega este carácter personal, como anota el mismo autor: "BIANCHI cree que es lícito al marido dar mandato a un tercero para autorizar a la mujer a realizar cualquiera de los actos para los que necesita licencia”, ya que la naturaleza jurídica del mandato preservaría la voluntad del marido, esto es, del mandante.

${ }^{68}$ MUÑOZ GARCÍA, M. J., op. cit., p. 106.

${ }^{69}$ LACRUZ BERDEJO, J. L., op. cit., p. 205.

${ }^{70}$ LACRUZ BERDEJO, J. L., La potestad doméstica..., pp. 206 y 207.
} 
no es susceptible de que el acto sean anulable ${ }^{, 71}$.

Conviene recordar también que la autoridad marital puede ser especial para un acto determinado o aquellos que se necesiten para alcanzar un resultado; o general para todos los negocios jurídicos (por ejemplo, el ejercicio del comercio) ${ }^{72}$ siendo indiferente que los actos sean de la misma naturaleza o no, pudiendo incluso alcanzar "todos los actos para los que el Código exige licencia, sin más especificación" "73. En este caso, es siempre revocable.

Planteadas estas observaciones, puede afirmarse que la situación en la que el sistema jurídico de la época encuadra a la mujer casada requería de un mecanismo que lo permitiese. Es por ello que considero esta institución como funcionalmente útil en ese determinado momento histórico, pues la licencia marital era el cauce jurídico que admitía dos contradicciones que se interconectaban: de un lado, el mantenimiento de esta menor capacidad o minoría de edad de la mujer, y de otro, su necesaria actuación en el tráfico jurídico ${ }^{74}$ para celebrar contratos, enajenar sus bienes, donar, ser heredera 0 legataria, etc., como se estudiará en las páginas sucesivas.

\section{V.- ACTOS QUE NO PODÍA REALIZAR LA MUJER CASADA.}

La familia se crea en torno al poder omnímodo del marido, quien organiza y dirige los intereses económicos y personales del matrimonio, y cuya autoridad imposibilita a la mujer para una serie de actos en el ámbito patrimonial y personal. Estos actos son los siguientes:

\section{En la esfera personal.}

A) El deber de obediencia de la mujer a su marido. Recogido en el originario art. 57 $\mathrm{Cc}^{75}$, refleja fielmente el art. 213 del Código napoleónico ${ }^{76}$. Este deber, basado en la ideología doméstica", se traduce en "la exigencia de un debido acatamiento a la voluntad jerarquizada del cabeza de familia, en los casos de discrepancia y conflicto, $y$ en tanto que no lastime esa obediencia la personalidad jurídica de la esposa"78. GOMÁ apunta la relación de fuerza y servidumbre ${ }^{79}$ que se deduce del artículo, similar a la relación de vasallaje entre siervo y señor de la época feudal. La forma de ser redactado transmite, por palabras de CASTÁN la idea de causa y efecto: obedecerás porque te protejo ${ }^{80}$. Por todo ello, piensa HINOJOSA ${ }^{81}$ que este artículo suscita más desventajas que

\footnotetext{
${ }^{71}$ MUÑOZ GARCÍA, M. J., op. cit., p. 106.

${ }^{72}$ LACRUZ BERDEJO, J. L., La potestad doméstica..., p. 205.

${ }^{73}$ LACRUZ BERDEJO, J. L., op. cit., p. 205.

${ }^{74}$ También en el tráfico mercantil, conforme a los artículos 6 a 9 del Código de comercio.

75 Art. 57 Cc de 1889: "El marido debe proteger a la mujer, y ésta obedecer al marido."

${ }^{76}$ Art. 213 del Código Civil Francés: "El marido debe protección a su mujer, la mujer obediencia a su marido."

${ }^{77}$ IMAZ ZUBIAUR, L., op. cit., p. 73.

${ }^{78}$ PÉREZ GONZÁLEZ, B., y CASTÁN TOBEÑAS, J., op. cit., p. 206.

${ }^{79}$ GOMÁ SALCEDO, J. E., Instituciones de Derecho Común Civil y Foral, Bosch, Barcelona, 2010, p. 416.

${ }^{80}$ CASTÁN TOBEÑAS, J., op. cit., p.202.

81 Ídem, p. 202.
} 
aportaciones, pudiendo ser eliminado del Código sin inconvenientes. Ante la imprecisión del precepto, debe entenderse que este deber de obediencia no tiene alcance absoluto $^{82}$, así refuerza DE CASTRO, para quien la esposa tiene un campo de actuación que gira en torno a "su propia persona y estado y a los derechos de su personalidad. Por lo que su ejercicio normal, aun contra la voluntad del marido, no es desobediencia ni conducta ilícita”83.

B) El deber de seguir la esposa a su marido donde quiera que fije su residencia, a tenor del art. $58 \mathrm{Cc}^{84}$. Si el marido traslada la residencia a Ultramar o a país extranjero, los Tribunales pueden exonerar a la mujer de esta obligación si concurren justas causas ${ }^{85}$.

C) El deber de seguir la esposa la condición y la nacionalidad de su marido, establecido en el art. $22 \mathrm{Cc}^{86}$. A pesar de que esta obligación se derogase en el $1954^{87}$, no libraba a la mujer casada a menos que estuviese separada legalmente. Por ende, seguía la ley personal de su consorte, hasta el punto de cambiar su nacionalidad; "y si la nacionalidad del marido cambiaba, la mujer le seguía siempre ${ } 88$.

D) En la patria potestad, la preferencia por el padre para su ejercicio sobre los hijos comunes, como estipula el art. 154. $1^{\circ} \mathrm{Cc}^{89}$.

Es importante incidir en el derecho de fiscalización por parte del marido de las relaciones personales de su esposa ${ }^{90}$, es decir, el control de la elección de la profesión, de la correspondencia, o vigilancia de visitas. Al igual que los actos anteriormente enumerados, el derecho de fiscalización constituye una limitación a la autonomía personal de la mujer que, sin embargo, se excluye del catálogo por no haber quedado dispuesto positivamente en el Código Civil - aunque sí ha sido recogido en el Código de Comercio-. En este tipo de actos, aclara DE CASTRO que ante la falta de acuerdo entre los cónyuges, la autoridad marital otorga el poder al marido para decidir y consecuentemente, "habrá que admitir una cierta facultad en aquél para intervenir la correspondencia de su esposa o fiscalizar sus relaciones (...) en lo estrictamente necesario al buen funcionamiento de la sociedad conyugal".

\footnotetext{
82 Ídem, pp. 173 y 174.

${ }^{83}$ DE CASTRO Y BRAVO, F., op. cit., pp. 260 y ss.

${ }^{84}$ Art. 58 Cc de 1889: La mujer está obligada a seguir a su marido donde quiera que fije su residencia. Los Tribunales, sin embargo, podrán con justa causa eximirla de esta obligación cuando el marido traslade su residencia a ultramar o a país extranjero.

${ }^{85}$ CASTÁN TOBEÑAS, J., op. cit., pp. 173 y 174.

${ }^{86}$ Art. 22 Cc de 1889: La mujer casada sigue la condición y nacionalidad de su marido. La española que casare con extranjero, podrá, disuelto el matrimonio, recobrar la nacionalidad española, llenando los requisitos expresados en el artículo anterior.

87 Art. 22 Cc con la reforma de 1954, párrafo $2^{\circ}$ : Perderán la nacionalidad española los que hubieran adquirido voluntariamente otra nacionalidad (...) La mujer casada no podrá por sí sola adquirir voluntariamente otra nacionalidad, a menos que esté separada legalmente.

${ }^{88}$ VILLANUEVA LUPIÓN, C., op. cit., p. 46.

${ }^{89}$ Art. 154.1 Cc de 1889: El padre, y en su defecto la madre, tienen potestad sobre sus hijos legítimos no emancipados; y los hijos tienen la obligación de obedecerles mientras permanezcan en su potestad, y de tributarles respeto y reverencia siempre.

${ }^{90}$ CASTÁN TOBEÑAS, J., op. cit., pp. 173 y 174.
}

\author{
Revista de Estudios Jurídicos n 15/2015 (Segunda Época) \\ ISSN 2340-5066. Universidad de Jaén (España) \\ Versión electrónica: rej.ujaen.es




\section{En la esfera patrimonial.}

La potestad marital se extiende también sobre los bienes y el patrimonio de la mujer. El hecho de contraer matrimonio comporta para ella, "hasta la década de los 70 del siglo $X X,(. .$.$) un recorte, más o menos acusado en los poderes de administración y gestión$ de los bienes" "1. Su régimen es mucho más represivo que el de la mujer soltera mayor de edad o viuda, pudiendo esta última participar en negocios jurídicos de compraventa, arrendamiento, o donación. Pese a estas libertades, no debe olvidarse que en la época que nos atañe, ninguna mujer, independientemente de su estado civil, se encuentra en plena igualdad jurídica con el hombre: "no puede ser tutora, ni testigo en testamento, ni adoptar, ni salir fiadora"92, entre otras limitaciones.

En concreto, los actos que no puede realizar la mujer casada y que repercuten en su patrimonio son los siguientes:

A) La prohibición de administración de la sociedad conyugal del art. $59 \mathrm{Cc}^{93}$, conforme al cual, solo el marido tiene el derecho de administrar los bienes matrimoniales en el régimen económico de sociedad de gananciales, art. 1412 $\mathrm{Cc}^{94}$; y la dote, art. $1357 \mathrm{Cc}^{95}$. De la administración se derivan facultades de disposición, por lo que el marido puede disponer, enajenar y obligar a título oneroso sin necesidad de que la mujer lo apruebe. Sin embargo, frente a la amplitud de actuación que el Código parece proveer, varios autores ${ }^{96}$ se manifiestan en contrario, ya que existen excepciones. "Por ejemplo -dice LACRUZ $^{97}$-, el art. 1384 Cc libera de la gestión del marido a la totalidad de los bienes de la mujer no entregados en administración, y deja al marido reducido, en realidad, a administrador de la comunidad de gananciales". No se admite pacto que permita eliminar estas facultades, porque la disposición y administración le vienen dadas por su condición y su supremacía como marido. En otras palabras, la capacidad para disponer es el "elemento irreductible en el papel del marido".

B) La restricción para realizar los actos dispuestos en los arts. 60 y 61 Cc.

\footnotetext{
${ }^{91}$ GETE-ALONSO Y CALERA, M. C., y SOLÉ RESINA, J., Mujer y patrimonio (el largo peregrinaje del siglo de las luces a la actualidad). Estudios monográficos, ADC, tomo LXVII, Barcelona, 2014, p. 774.

${ }^{92}$ MUÑOZ GARCÍA, M. J., op. cit., p.19.

93 Art. 59 Cc de 1889: El marido es el administrador de los bienes de la sociedad conyugal, salvo estipulación en contrario y lo dispuesto en el artículo 1.384. Si fuere menor de dieciocho años, no podrá administrar sin el consentimiento de su padre; en defecto de éste, sin el de su madre, y a falta de ambos, sin el de su tutor. Tampoco podrá comparecer en juicio sin la asistencia de dichas personas. En ningún caso, mientras no llegue a la mayor edad, podrá el marido, sin el consentimiento de las personas mencionadas en el párrafo anterior, tomar dinero a préstamo, gravar ni enajenar los bienes raíces.

${ }^{94}$ Art. 1412 Cc de 1889: El marido es el administrador de la sociedad de gananciales, salvo lo dispuesto en el artículo 59.

${ }_{95}$ Art. 1357 Cc de 1889: El marido es administrador y usufructuario de los bienes que constituyan la dote inestimada, con los derechos y obligaciones anexos a la administración y al usufructo, salvas las modificaciones expresadas en los artículos siguientes.

${ }^{96}$ CASTÁN TOBEÑAS, J., op. cit., pp. 174 y 175.

${ }^{97}$ LACRUZ BERDEJO, J. L., op. cit., p. 180.
} 
a) $\quad \mathrm{El}$ art. $60 \mathrm{Cc}^{98}$ instaura la representación de la mujer por el marido, y le impide comparecer en juicio sin la licencia marital. El precepto, cuyo origen se sitúa en las Leyes de Toro, no contiene el alcance de la representación, si bien se entiende como limitada, destinada a unos objetivos específicos, debiendo "ajustarse al cumplimiento de los requisitos que de otros preceptos de la ley se deducen como necesarios" "99. Parte de la doctrina ${ }^{100}$ considera que el Código admite tanto la representación en procesos judiciales como extrajudiciales y, de acuerdo a una lectura literal del artículo, independientemente de si esta representación se ejerce por un marido mayor o menor de edad.

Asimismo, la representación ha sido interpretada en dos vertientes. Para la doctrina moderna ${ }^{101}$, ésta se equipara a la representación que tienen los incapacitados; para la doctrina clásica $^{102}$ en cambio, consiste en "una manifestación de la tutela jurídica del interés y el bien común en los dominios de la sociedad conyugal" "103, y no una representación como tal, porque "si el marido fuera realmente el representante de su mujer, la mujer no podría comparecer en juicio de ninguna manera, y sería dicho marido el que procedería en nombre de la mujer" ${ }^{104}$. Esta diferencia de posiciones se reduce al ya discutido debate de capacidad de la mujer, por lo que no es pertinente reincidir en el tema.

En los años 50 y 60, la representación fue entendida por la doctrina y la jurisprudencia como voluntaria: el marido celebra negocios jurídicos e interviene en procedimientos judiciales como lo haría un representante voluntario, actuando solo válidamente (es decir, surtiendo efectos) con la aprobación de la mujer, lo que excluye la posibilidad de una extralimitación en la facultad de representación, al requerirse para cada acto "la ratificación, si quiera tácita, de la mujer”, necesaria para poder vincularla.

Finalmente, cabe matizar aquí una conclusión obvia: el otorgamiento de licencia extingue la posibilidad de representación del marido; o el marido representa a su esposa, o bien la mujer actúa en el tráfico con la licencia marital: "son dos soluciones alternativas, pero nunca simultáneas: o se acepta la una o la otra, aunque el Código parece como si las creyera compatibles, porque acepta ambas en los art. 60 y 61 Cc”.

\footnotetext{
${ }^{98}$ Art. 60 Cc de 1889: El marido es el representante de su mujer. Ésta no puede, sin su licencia, comparecer en juicio por sí o por medio de Procurador. No necesita, sin embargo, de esta licencia para defenderse en juicio criminal, ni para demandar o defenderse en los pleitos con su marido, o cuando hubiere obtenido habilitación conforme a lo que disponga la Ley de Enjuiciamiento Civil.

${ }^{99}$ LACRUZ BERDEJO, J. L., op. cit., p. 182.

${ }^{100}$ SÁNCHEZ ROMÁN y VALVERDE, según LACRUZ BERDEJO J. L., op. cit., p. 181.

${ }^{101}$ Como SANTAMARÍA ROJAS, A., La autoridad marital en la vida, Reus, Madrid, 1951, pp.72 y ss; o GÓMEZ MORÁN, L., op. cit.

${ }^{102}$ Como DE CASTRO Y BRAVO, F., Derecho Civil de España. T.II, Vol.1º, Madrid, 1952, p. 258; o COSSÍO Y CORRAL, A., La potestad..., pp. 27 y ss.

${ }^{103}$ CASTÁN TOBEÑAS, J., op. cit., p. 183.

${ }^{104}$ LACRUZ BERDEJO, J. L., op. cit., p. 183.
} 
b) El art. $61 \mathrm{Cc}^{105}$ prohíbe a la mujer casada adquirir a título oneroso o lucrativo, enajenar sus bienes u obligarse sin licencia marital, salvo los casos establecidos en la ley. Estas salvedades que menciona el Código son, por un lado, las facultades conferidas a la mujer para desempeñar sus labores en el hogar potestad doméstica-; y por otro, el poder de administración y disposición sobre sus bienes privativos: aquellos que no constituyen bienes dotales ni bienes matrimoniales -bienes parafernales ${ }^{106}$-. Para las adquisiciones lucrativas debe estarse a lo dispuesto en el art. $626 \mathrm{Cc}^{107}$ y $995 \mathrm{Cc}^{108}$, los cuales niegan la aceptación de donaciones a las personas sin capacidad, cuando actúen sin su representante; y la aceptación y repudiación de herencia por la esposa, respectivamente.

Las adquisiciones onerosas, comenta LACRUZ ${ }^{109}$ se regirán por el articulado de las obligaciones y las enajenaciones. Éstas engloban multitud de negocios jurídicos, como la permuta, la dación en pago, constitución de sociedades, o la tan importante compraventa, entre otras. La prohibición de enajenar alcanza tanto la transferencia de bienes como la constitución de derechos reales sobre cosas ajenas $^{110}$.

Para las obligaciones deben observarse los art. $893.2^{\circ} \mathrm{Cc}^{111}$ y $1716.2^{\circ} \mathrm{Cc}^{112}$, como explica LACRUZ, donde se impide a la mujer casada ejercer como albacea y ser mandante sin autorización marital. Esta prohibición de obligarse es interpretada en stricto sensu por la doctrina ${ }^{113}$, pues solo va indicado para obligaciones contractuales. Según este autor, el art. 61 Cc, esencial en la institución de la autoridad marital, es "el verdadero sistema del Código Civil (...) el de la licencia marital para muchos de los actos de la mujer" "114; sobre la que se estructuran el conjunto de poderes del marido.

\footnotetext{
${ }^{105}$ Art. 61 Cc de 1889: Tampoco puede la mujer, sin licencia o poder de su marido, adquirir por título oneroso ni lucrativo, enajenar sus bienes, ni obligarse, sino en los casos y con las limitaciones establecidas por la Ley.

${ }^{106}$ GETE-ALONSO Y CALERA, M. C., y SOLÉ RESINA, J., op. cit., p. 775, explican que "los bienes parafernales, de procedencia griega, hacen referencia a bienes que "están fuera de la dote, es decir que no se integran en ella y, por lo tanto, tienen un régimen diferenciado".

107 Art. 626 Cc de 1889: Las personas que no pueden contratar no podrán aceptar donaciones condicionales u onerosas sin la intervención de sus legítimos representantes.

${ }^{108}$ Art. 995 Cc de 1889: La mujer casada no podrá aceptar ni repudiar herencia sino con licencia de su marido, o, en su defecto, con aprobación del Juez. En este último caso no responderán de las deudas hereditarias los bienes ya existentes en la sociedad conyugal.

${ }^{109}$ LACRUZ BERDEJO, J. L., op. cit., p. 186.

${ }^{110} \mathrm{Al}$ decir LACRUZ que la enajenación también abarca "la constitución de cualesquiera iura in re aliena”, en la misma página.

${ }^{111}$ Art. 893 Cc de 1889: No podrá ser albacea el que no tenga capacidad para obligarse. La mujer casada podrá serlo con licencia de su marido, que no será necesaria cuando esté separada legalmente de él. El menor no podrá serlo, ni aun con la autorización del padre o del tutor.

${ }^{112}$ Art. 1716 Cc de 1889: El menor emancipado puede ser mandatario; pero el mandante sólo tendrá acción contra él en conformidad a lo dispuesto respecto a las obligaciones de los menores. La mujer casada sólo puede aceptar el mandato con autorización de su marido.

${ }^{113}$ LACRUZ BERDEJO, J. L., op. cit., p. 187.

114 Ídem, p. 183.
} 
Como se observa, el Código Civil, especialmente en materia de derecho matrimonial, ha tratado mediante su articulado de adecuarse y reforzar la supremacía y poder de gobierno del varón, promoviendo aquellas medidas que resultasen más ventajosas para su patrimonio. Muy acertadamente ha dicho RAMS ALBESA, en su prólogo a la importante obra del profesor LACRUZ que, bajo el pretexto de la ya conocida unidad de dirección, "se ha adornado la condición económica del marido, de forma que pareciese real, verdadera, justa, moral, equitativa y fuera de duda alguna la repetida y no justificada frase jurisprudencial que consagraba al marido como dueño y señor de los bienes incorporados a la economía familiar y único titular con plena capacidad de disposición de los bienes mismos”115.

\section{VI.- ACTOS QUE PODÍA REALIZAR LA MUJER CASADA.}

Además de las dos excepciones del art. $61 \mathrm{Cc}^{116}$, el ordenamiento jurídico, con cierta ambigüedad, permite a la mujer realizar los actos descritos en el art. $63 \mathrm{Cc}^{117}$, a saber:

- Otorgar testamento. Entiende LACRUZ que "el motivo para limitar las facultades de la mujer casada es la unidad de acción constante el matrimonio, y no la ineptitud de ésta para vincularse"118, lo que permite otorgar válidamente contratos sucesorios sin la autoridad marital.

- $\quad$ Ejercer los derechos y cumplir los deberes que le correspondan respecto a los hijos legítimos $^{119}$, o naturales reconocidos que hubiese tenido de otro, y respecto a los bienes de los mismos. La doctrina ${ }^{120}$ ha incluido también las facultades de la madre sobre sus hijos no reconocidos $^{121}$ e ilegítimos ${ }^{122}$.

\footnotetext{
${ }^{115}$ RAMS ALBESA, J., prólogo de la obra de Derecho de familia. El matrimonio y su economía, de LACRUZ BERDEJO, José Luis, Civitas, Tratado teórico-práctico de Derecho civil, Tomo IV, Volumen $1^{\circ}$, Barcelona, 1963.

${ }^{116}$ Esto es, las facultades de disposición y administración de los bienes parafernales y para los actos que se deriven del ejercicio de la potestad doméstica.

${ }^{117}$ Art. 63 Cc de 1889: Podrá la mujer sin licencia de su marido: 1. ${ }^{\circ}$ Otorgar testamento. 2. ${ }^{\circ}$ Ejercer los derechos y cumplir los deberes que le correspondan respecto a los hijos legítimos o naturales reconocidos que hubiese tenido de otro, y respecto a los bienes de los mismos.

${ }_{118}^{11}$ LACRUZ BERDEJO, J. L., op. cit., p. 188.

119 Art. 114 Cc de 1889: Los hijos legítimos tienen derecho: $1 .^{\circ}$ A llevar los apellidos del padre y de la madre. 2. ${ }^{\circ}$ A recibir alimentos de los mismos, de sus ascendientes y, en su caso, de sus hermanos, conforme al artículo 143. 3. ${ }^{\circ}$ A la legítima y demás derechos sucesorios que este Código les reconoce.

Art. 154 Cc de 1889: El padre, y en su defecto la madre, tienen potestad sobre sus hijos legítimos no emancipados; y los hijos tienen la obligación de obedecerles mientras permanezcan en su potestad, y de tributarles respeto y reverencia siempre. Los hijos naturales reconocidos, y los adoptivos menores de edad, están bajo la potestad del padre o de la madre que los reconoce o adopta y tienen la misma obligación de que habla el párrafo anterior.

${ }^{120}$ CASTÁN TOBEÑAS, J., op. cit., p. 175.

${ }^{121}$ Art. 136 Cc de 1889: La madre estará obligada a reconocer al hijo natural: $1 .^{\circ}$ Cuando el hijo se halle, respecto de la madre, en cualquiera de los casos expresados en el artículo anterior. $2 .^{\circ}$ Cuando se pruebe cumplidamente el hecho del parto y la identidad del hijo.

${ }^{122}$ Art. 139 Cc de 1889: Los hijos ilegítimos, en quienes no concurra la condición legal de naturales, sólo tendrán derecho a exigir de sus padres alimentos conforme al artículo 143.
} 
Además de lo dispuesto en este artículo ${ }^{123}$, la mujer casada queda facultada por el art. 1413 Cc $^{124}$ para actuar cuando el marido disponga, administre o enajene los bienes conyugales de forma fraudulenta o contraria a la ley, causando perjuicio a la mujer; así como para exigir la constitución de hipoteca e inscripción de los bienes dotales, en virtud del art. 1352 Cc $^{125}$. También puede, según el art. $60.2^{\circ}$ Cc, defenderse en juicio criminal, demandar y defenderse en los pleitos de su marido.

Asimismo, se admite la titularidad de la mujer casada sobre los bienes parafernales y la administración de los mismos. De iure, el derecho civil construye a favor de la mujer casada facultades y derechos nada despreciables; tiene cierto margen de maniobrabilidad en torno a sus bienes y derechos, siendo titular del derecho de propiedad, de derechos relativos a las disposiciones mortis causa y derivados de la filiación.

Sin embargo, el optimismo de estas líneas desaparece cuando se toma debida cuenta de la realidad de la época. Así lo expresan diferentes autores, pues las limitaciones para ejercer estas facultades "han resultado, para la mujer, tan imponentes que no han sido más que formas indirectas de vaciar de contenido el derecho 'formalmente' reconocido, hasta dejarlo inerte" ${ }^{\text {126. }}$

\section{VII.- LA POTESTAD DOMÉSTICA: NATURALEZA JURÍDICA.}

Ya se comentaba el poder de administración dentro del hogar de la mujer. Con la llamada potestad doméstica, recogida en los art. $62^{127}$ y $1362 \mathrm{Cc}^{128}$, el ordenamiento jurídico dota a la esposa de un conjunto de facultades "en orden a la realización de los gastos domésticos sin autorización del marido" ${ }^{129}$, como secuela histórica ${ }^{130}$ de lo que ha sido un poder en la mujer vinculado a su función en el hogar. Pero estas facultades se limitan al fin previsto en el art. 62 Cc. La potestad doméstica se concede para todo acto que "por su naturaleza esté destinado al consumo ordinario de la familia”; es decir,

\footnotetext{
${ }^{123}$ CASTÁN TOBEÑAS, J., op. cit., p.175, recuerda que fuera del Código Civil, la esposa podía “pedir el depósito judicial en caso de intentar o haber intentado demanda de divorcio, querella de amancebamiento o acción de nulidad del matrimonio (art. 1880 LEC)”.

124 Art. 1413 Cc de 1889: Además de las facultades que tiene el marido como administrador, podrá enajenar y obligar a título oneroso los bienes de la sociedad de gananciales sin el consentimiento de la mujer. Sin embargo, toda enajenación o convenio que sobre dichos bienes haga el marido, en contravención a este Código o en fraude de la mujer, no perjudicará a ésta ni a sus herederos.

${ }^{125}$ Art. 1352 Cc de 1889: La mujer casada mayor de edad puede exigir por sí misma la constitución de hipoteca e inscripción de bienes de que trata el artículo 1.349 .

${ }^{126}$ IMAZ ZUBIAUR, L., op. cit., p. 73.

${ }^{127}$ Art. 62 Cc de 1889: Son nulos los actos ejecutados por la mujer contra lo dispuesto en los anteriores artículos, salvo cuando se trate de cosas que por su naturaleza estén destinadas al consumo ordinario de la familia, en cuyo caso las compras hechas por la mujer serán válidas. Las compras de joyas, muebles y objetos preciosos, hechas sin licencia del marido, sólo se convalidarán cuando éste hubiese consentido a su mujer el uso y disfrute de tales objetos.

${ }^{128}$ Art. 1362 Cc de 1889: Los bienes de la dote inestimada responden de los gastos diarios usuales de la familia, causados por la mujer o de su orden bajo la tolerancia del marido; pero en este caso deberá hacerse previamente excusión de los bienes gananciales y de los del marido.

${ }^{129}$ CASTÁN TOBEÑAS, J., op. cit., p.177.

${ }^{130}$ Para LACRUZ BERDEJO, J. L., op. cit., pp. 198 y 199, “cabe reconocer una autoridad de la mujer en la familia, concedida por la costumbre y los usos sociales”.
} 
puede comprar empleando dinero procedente de la dote o de la masa conyugal para lo relativo a la alimentación, educación, transporte usual, cuidado corporal, entretenimiento, vestido, menaje, etc, según interpreta la doctrina ${ }^{131}$.

Como se observa, los gastos deben ser habituales -o como expresa LACRUZ, usuales, lo que dependerá del núcleo familiar del que se trate y está sujeto a esta subjetividad ${ }^{132}$-, módicos, necesarios para el desarrollo de las labores domésticas -lo que denomina como domesticidad ${ }^{133}$ del negocio jurídico-, pues "el poder doméstico versa sobre necesidades que se repiten, unas con periodicidad y otras sin ella, pero que normalmente hacen aparecer el acto de la mujer como una sustitución de objetos ya existentes en el hogar o como una adquisición de artículos, fuerzas o elementos que se consumen constante o periódicamente”. Los gastos extraordinarios, sin embargo, son únicamente decisión del marido, como se constata de la disposición al excluir los muebles, las joyas y los objetos preciosos.

La potestad doméstica es uno de campos de acción que quedan excluidos de la autoridad marital. Así, "en la esfera doméstica, la mujer casada contrata válidamente sin licencia y obliga a su marido a la comunidad conyugal”" ${ }^{134}$. Esto le permite actuar en el tráfico jurídico y administrar, en cierto modo, bienes dotales y de la sociedad conyugal, para poder cumplir con sus labores de ama de casa, madre y esposa como se requiere.

Estas facultades sobre bienes que el Código restringe supone para muchos "una esfera autónoma importantísima”135. ROYO MARTINEZ ${ }^{136}$ aprecia que “esta, al parecer, insignificante excepción -al poder del marido-, tiene una gran importancia práctica. De un lado, porque implica el reconocimiento legal de una cierta soberanía o autonomía hogareña; y del otro lado, porque en todas las clases humildes y aún medias, la adquisición de artículos para el consumo ordinario de la familia absorbe la mayor parte de los ingresos”.

Sin lugar a dudas, la institución se erige como la puerta que abre a la esposa facultades de actuación sobre bienes vetados que le permitan cumplir con sus obligaciones en la casa. "Sin la potestad domestica -dice LACRUZ ${ }^{137}$ - serían nulos los negocios que celebrase en el desarrollo de sus habituales actividades domésticas, y el interés de la familia y de los terceros exige que no ocurra así”. Y esto es un punto clave a mi parecer, porque permite comprender la aspiración del legislador: la potestad doméstica trata de beneficiar al núcleo familiar; en último extremo al marido, para quien ejerce sus tareas y a quien debe complacer. $\mathrm{Y}$ dado que se instituye con estos fines, es lógico

\footnotetext{
${ }^{131}$ CASTÁN TOBEÑAS, J., op. cit., p. 177; o LACRUZ BERDEJO, J. L., La potestad doméstica..., p. 57, entre otros.

${ }^{132}$ LACRUZ BERDEJO, J. L., op. cit., p. 199, comenta que “los gastos serán usuales y las cosas corrientes según el tenor de la vida en familia, la clase a que pertenece, y la concepción que de esta clase se tiene económica y socialmente".

${ }^{133}$ Para LACRUZ BERDEJO, J. L., op. cit., p. 199, la domesticidad del acto se valorará mediante "el hecho concreto, y en él la cuantía del gasto en relación con el medio social a que pertenece la familia”.

${ }^{134}$ LACRUZ BERDEJO, J. L., La potestad doméstica..., p.5

135 LACRUZ BERDEJO, J. L., op. cit., p. 198

${ }^{136}$ ROYO MARTÍNEZ, M., Derecho de familia, Sevilla, 1949, p. 117; también CASTÁN TOBEÑAS, J., op. cit., p.177.

${ }^{137}$ LACRUZ BERDEJO, J. L., op. cit., p. 198.
} 
entender que de las deudas contraídas o de los actos que se realicen en el ejercicio de la potestad doméstica no responden en primer lugar los bienes privativos de la mujer, sino los bienes conyugales ${ }^{138}$; en caso de no ser suficientes, los bienes privativos del marido; y finalmente, los bienes de la dote. "Por lo tanto, la mujer tiene una responsabilidad subsidiaria, solo a falta de recursos de la comunidad conyugal y del marido responden los bienes dotales y parafernales ${ }^{139 " 140}$, lógicamente, pues actúa en beneficio de la familia.

Finalmente, ha creado cierta discusión la determinación de su naturaleza a efectos legales. Parte de la doctrina predominante en la época ${ }^{141}$ ha observado el art. 62 Cc como un mandato tácito del marido, "derivado de la presunción de que éste le atribuye el encargo de realizar los gastos necesarios para atender a las necesidades cotidianas del hogar”, por dos razones. La primera de ellas, porque los negocios jurídicos que realiza la mujer en base a esta potestad son susceptibles de revocabilidad; la segunda, porque ante la separación judicial o de hecho de los cónyuges, se elimina dicho mandato al carecer de sentido.

Contrario a esta corriente de opinión es DE CASTRO, al considerar que los caracteres legales de la potestad doméstica no coinciden con los del mandato: "porque para la eficacia del acto en el mandato requiere que se haga por cuenta y encargo del marido $^{142}$ y sin traspasar los límites del mandato ${ }^{143}$, y porque ni la mujer ni sus bienes quedarían obligados, sino solo los del marido, como mandante" ${ }^{144}$. Tampoco COSSÍO equipara la potestad doméstica al mandato, en tanto que "la mujer utiliza un derecho que, excepcionalmente, la ley le reconoce. No debe admitirse que el marido pueda privarle de esta facultad" ${ }^{145}$, negando su posible revocabilidad, opinión a la que me sumo.

Por otra parte, también ha llegado a considerarse la potestad doméstica como una vertiente de la representación legal, aunque esta teoría no se sostiene. De ser así, sólo los bienes del marido quedarían afectos a la responsabilidad; además, se precisaría que la esposa declarase que los actos o negocios jurídicos que realiza son en nombre de su marido, lo que conlleva el requisito de la contemplatio domini ${ }^{146}$.

\footnotetext{
138 Art. 1408.1 ${ }^{\circ}$ Cc de 1889: Serán de cargo de la sociedad de gananciales: $1 .^{\circ}$ Todas las deudas y obligaciones contraídas durante el matrimonio por el marido, y también las que contrajere la mujer en los casos en que pueda legalmente obligar a la sociedad.

139 Art. 1385 Cc de 1889: Los frutos de los bienes parafernales forman parte del haber de la sociedad conyugal y están sujetos al levantamiento de las cargas del matrimonio. También lo estarán los bienes mismos en el caso del artículo 1.362, siempre que los del marido y los dotales sean insuficientes para cubrir las responsabilidades de que allí se trata.

${ }^{140}$ CASTÁN TOBEÑAS, J., op. cit., p. 177.

${ }^{141}$ Entre ellos, CASTÁN TOBEÑAS, J., op. cit., p. 181.

142 Art. 1709 Cc de 1889: Por el contrato de mandato se obliga una persona a prestar algún servicio o hacer alguna cosa, por cuenta o encargo de otra.

${ }^{143}$ Art. 1714 Cc de 1889: El mandatario no puede traspasar los límites del mandato.

${ }^{144}$ DE CASTRO Y BRAVO, F., op. cit., pp. 265.

${ }^{145}$ COSSÍO Y CORRAL, A., op. cit., pp. 23 y ss.

${ }^{146}$ Contemplatio domini o la actuación en nombre ajeno, supone que "las partes conocen la existencia de un dominus detrás de la actuación del representante”.
} 


\section{VIII.- PRIMERAS REFORMAS JURÍDICAS DEL ESTATUS DE LA MUJER.}

En la década de los 50, la doctrina civilista empezó a tomar consciencia de la problemática jurídica ${ }^{147}$ y del germen de cambio que empezaba a brotar de la legislación. "No cabe duda, -comentaba PAJOT ${ }^{148}$ en el año 54,- de que la evolución de los derechos de la mujer, orientada a través de una progresiva emancipación, pretendiendo llegar hasta una total igualdad con el marido, constituye una de las características de los tiempos actuales”.

La realidad socioeconómica comienza a moldear los estándares impuestos por el régimen y la tradición, adentrándose en el mundo jurídico mediante la renovación de preceptos, tendentes a erradicar las muestras más duras, represivas y discriminatorias para la mujer. De hecho, la ampliación de derechos que empezó a materializarse era ya cuestión urgente desde principios del siglo XX para un gran número de voces que se vieron silenciadas durante más de 50 años ${ }^{149}$.

Así con todo, un arraigado sector convencional negaba cualquier mejora en su condición jurídica. Las mujeres, y aún más, las esposas, seguían encorsetadas por aquellos derechos que fueran imprescindibles para el correcto cumplimiento de sus funciones ${ }^{150}$.

Incluso intelectuales de renombre y juristas de gran calado en nuestro ordenamiento propugnaban el mantenimiento de las desigualdades entre los cónyuges -y en general, entre el hombre y la mujer- en aras a la unidad de dirección y el orden social ${ }^{151}$.

$\mathrm{Al}$ respecto, tres años antes de la promulgación de la Ley de $1958^{152}$, de la que partimos como base del cambio hacia la igualdad jurídica, el jurista ${ }^{153}$ considera “deseables

\footnotetext{
${ }^{147}$ Indica RAMS ALBESA, J., en el prólogo de la obra de LACRUZ BERDEJO, J. L., Derecho de familia. El matrimonio y su economía, Civitas, Tratado teórico-práctico de Derecho civil, Volumen $1^{\circ}$, Tomo IV, 1963, Barcelona, que "en la sociedad española de los años cincuenta se estaba produciendo una renovación de gran calado, aunque muy poco visible, en los estudios de derecho (...) de forma destacada en el tradicional Civil".

${ }^{148}$ PAJOT, G., "La mujer casada en el derecho comparado", Revista de derecho notarial, Traducción de Ángel Blanco Soler, Madrid, 1954, p. 140.

${ }^{149}$ Por ejemplo, las obras: FERREIRO LAGO, R., Condición jurídica de la mujer, Valladolid, 1902; DE BURGOS Y SEGUÍ, C., La mujer moderna y sus derechos, Madrid, 1927; ROMERA NAVARRO, M., Feminismo Jurídico, Madrid, 1910; POSADA, A., Feminismo, Madrid, 1899; OSSORIO y GALLARDO, Á., Cartas a una muchacha sobre temas de derecho civil, Madrid, 1925; entre otros, en CASTÁN TOBEÑAS, J., op. cit., p.190

${ }^{150}$ Así lo refleja RUIZ FRANCO, R., op. cit., p. 27, al decir que "el sistema jurídico franquista no veía a las mujeres como sujetos de derechos inherentes a su condición de seres humanos, sino como seres obligados por una función social específica".

${ }^{151}$ Afirmaba sin reserva CASTÁN TOBEÑAS, J., op. cit., pp.220 y 221, que "no debemos aferrarnos, con actitud retrógrada, a las formas de vida que ya pasaron. Mas tampoco debemos los juristas anticiparnos a la transformación social (...) todo se perdería si al reconocer a la mujer sus valores humanos y sus derechos naturales, protegiendo su libertad y su dignidad, pusiésemos en peligro su feminidad y olvidásemos el interés primordial de la conservación de la familia”.

${ }^{152}$ Ley de 24 de abril de 1958, publicado en el BOE, el 25 de abril de 1958.

${ }^{153}$ CASTÁN TOBEÑAS, J., op. cit., p. 198.
} 
algunas reformas ${ }^{154}$ en orden a los derechos de la mujer (...) pero la actual situación legislativa y social no es tan injusta con el sexo femenino que reclame tales reformas salvo algunos posibles detalles- con caracteres de gran urgencia”. A tenor de esta reflexión, ROYO MARTINEZ mantiene el poder del marido como necesario para el buen fin de la unidad familiar, sin perjuicio de que el Código "necesite profundas correcciones en orden a la capacidad de obrar que a la mujer casada reconoce” ${ }^{155}$.

Entre estas reformas que apreciaban debían cambiarse, están: los artículos que impiden a la mujer ocupar cargos tutelares ${ }^{156}$; ser testigo en los testamentos ${ }^{157}$; o vocal del consejo de familia ${ }^{158}$; preceptos que afectan a toda mujer independientemente de su estado civil. En cuanto a la mujer casada, se solicita la reforma del art. $105.1^{\circ} \mathrm{Cc}^{159}$ por considerar causa legítima de divorcio el adulterio de la mujer siempre, y solo respecto al varón cuando sea escándalo público, ya que "la ofensa es igual viniendo del marido o de la mujer" ${ }^{160}$; el art. 57 Cc en cuanto a la obediencia debida de la mujer al varón, por considerarse "vejatorio para la mujer y sin consecuencias legales prácticas" 161; matizar el art. 58 Cc por el que la mujer debe seguir al marido; ampliar los derechos de la mujer, con especial referencia a los derechos patrimoniales; y por último, mejorar la técnica legislativa de la institución de la licencia marital en sus aspectos más imprecisos.

\section{Ley de 24 de abril de 1958.}

De todo lo anterior, se promulga en plena ebullición jurídica la Ley de 24 de abril de 1958, como respuesta a la demanda social. Entre sus propósitos ${ }^{162}$, incide en la ampliación de la capacidad jurídica de la mujer y la modificación del régimen económico matrimonial de gananciales.

En la Exposición de Motivos la Ley reconoce la existencia de un rígido articulado que

\footnotetext{
${ }^{154}$ Entiende CASTÁN TOBEÑAS, J., op. cit., p. 199, como apropiado modificar disposiciones concretas, aquellas que afecten a la capacidad civil de la mujer pero sin trastocar el régimen establecido en derecho de familia ni el articulado relativo al régimen matrimonial.

${ }^{155}$ Ahora bien, ROYO MARTÍNEZ, M., op. cit., p. 109, no aprecia las disposiciones del Código como "opresoras, ni contrarias a deseos femeninos de mayor independencia, ni depresivas para la mujer en la estimación social (...) salvo casos excepcionales de matrimonios mal avenidos”.

${ }^{156}$ Art. 237.7 Cc de 1889: No pueden ser tutores ni protutores (...) $7 .^{\circ}$ Las mujeres, salvo los casos en que la ley las llama expresamente.

${ }^{157}$ Art. 681.1 $1^{\circ}$ Cc de 1889: No podrán ser testigos en los testamentos (...) $1 .^{\circ}$ Las mujeres, salvo lo dispuesto en el artículo 701.

${ }^{158}$ Art. 298 Cc de 1889: Las causas que excusan, inhabilitan y dan lugar a la remoción de los tutores y protutores son aplicables a los vocales del consejo de familia. No podrán tampoco ser vocales las personas a quienes el padre, o la madre, en su caso, hubiesen excluido en su testamento de este cargo.

${ }^{159}$ Art. 105 Cc de 1889: Las causas legítimas del divorcio son (...) $1 .^{a}$ El adulterio de la mujer en todo caso, y el del marido cuando resulte escándalo público o menosprecio de la mujer.

${ }^{160}$ CASTÁN TOBEÑAS, J., op. cit., p. 202.

${ }^{161}$ Ídem, p. 204.

162 BATLLE VÁZQUEZ, M., “Observaciones sobre la reforma del Código Civil”, Seminario de derecho privado de Murcia, Murcia, 1958, p. 3, dispone que otros motivos por los que se instauró la Ley eran: modificar los derechos sucesorios del cónyuge supérstite, mediante la instauración del usufructo; modificar la filiación adoptiva; y adaptar el sistema matrimonial español al concordato con la Santa Sede de 1953.
} 
responde a un trato desigual entre los cónyuges ${ }^{163}$ y rechaza la razón del sexo como causa de diferenciación entre ambos, pues “tanto en un orden natural como en el orden social, el sexo por sí solo no puede determinar en el campo del derecho civil una diferencia de trato que se traduzca, en algún modo, en la limitación de la capacidad de la mujer". De esta lectura entiendo que la desigualdad no viene de la condición biológica de la mujer; viene de otras causas: del matrimonio.

Asimismo, se hace referencia a una posición peculiar de la esposa, "en la que, por exigencias de la unidad matrimonial, existe una potestad de dirección, que la naturaleza, la Religión y la Historia atribuyen al marido”. Este párrafo es toda una declaración de intenciones. Aunque la reforma se instituye como uno de los primeros atisbos hacia la consecución de derechos, instituciones como la licencia marital o la potestad doméstica estaban todavía muy lejos de desaparecer ${ }^{164}$.

"Para liberar a la mujer de ciertas limitaciones en su capacidad" se reformaron los siguientes artículos: el art. $237 \mathrm{Cc}^{165}$, sustituyendo en el apartado $7^{\circ}$ la prohibición a toda mujer para ser tutora o protutora por la prohibición a la mujer casada sin licencia; los art. $294^{166}$ y $295^{167} \mathrm{Cc}$, por los que se permite a la mujer ser parte del consejo de familia; y el art. $681.1^{\circ} \mathrm{Cc}^{168}$, eliminando la prohibición a la mujer de ser testigo en los testamentos.

También dentro del matrimonio, son destacables las siguientes modificaciones: el controvertido art. $105.1^{\circ} \mathrm{Cc}^{169}$, estableciendo como causa de separación (antes de la Ley, causa de divorcio) el adulterio de alguno de los cónyuges; y el art. $168 \mathrm{Cc}^{170}$, conforme al cual, la madre que contrae segundas nupcias sigue teniendo la patria

\footnotetext{
${ }^{163}$ CASTÁN TOBEÑAS, J., op. cit., pp.155 y ss; DE CASTRO Y BRAVO, F., op. cit., pp. 241 y ss.

${ }^{164}$ De la misma opinión es CASTÁN TOBEÑAS, J., op. cit., p.116, al argumentar varios años antes de la promulgación de la Ley que “la supremacía que, en condiciones normales corresponde al marido se basa en una tradición histórica, reflejada en leyes y costumbres muy antiguas y reiteradas. Dicha tradición no puede ser tildada de arbitraria, pues tiene sus raíces en condiciones biológicas diferentes que, aun sin causar superioridad ni inferioridad en cada uno de los sexos, les acompañan perennemente”.

165 Art. 237. $7^{\circ}$ Cc con la reforma del 1958: No pueden ser tutores ni protutores (...) $7^{\circ}$ Las mujeres casadas que no hubieren obtenido licencia de su marido.

${ }^{166}$ Art. 294 Cc con la reforma del 1958, párrafo $1^{\circ}$ : El Consejo de Familia se compondrá de las personas que el padre, o la madre, en su caso, hubiesen designado en su testamento, y en su defecto, de los ascendientes y descendientes y de los hermanos del menor o incapacitado, cualquiera que sea su número y sexo. Si no llegaren a cinco, se completará con los parientes más próximos; y, si no los hubiere, o no estuvieren obligados a tomar parte del Consejo, el Juez nombrará en su lugar personas honradas, prefiriendo a los amigos de los padres del menor o incapacitado.

${ }^{167}$ Art. 295 Cc con la reforma de 1958: Para el Consejo de Familia será preferido el grado más próximo al más remoto; en igualdad de grado, el varón a la mujer, y en igualdad de grado y sexo, la persona de más edad.

${ }^{168}$ Art. $681.1^{\circ}$ Cc con la reforma de 1958: No podrán ser testigos en los testamentos: $1^{\circ}$. Los menores de edad, salvo lo dispuesto en el artículo setecientos uno.

169 Art. $105.1^{\circ}$ Cc con la reforma de 1958: Las causas legítimas de separación son: $1^{\circ}$ El adulterio de cualquiera de los cónyuges.

${ }^{170}$ Art. 168 Cc con la reforma de 1958: Las ulteriores nupcias del padre o de la madre no afectarán a la patria potestad; pero el Juez podrá conceder la emancipación de los hijos mayores de dieciocho años, si lo pidieren, previa audiencia del padre o madre.
} 
potestad sobre sus hijos ${ }^{171}$. Especial mención requieren los art. $67^{172}$ y $68.2^{\circ} \mathrm{Cc}^{173}$. El primero de ellos "introduce la posibilidad de que la mujer que pretendiera separarse (...) pudiera pedir provisionalmente que se le separara del marido, se le confiriera los hijos menores de 7 años, un domicilio y un auxilio económico a cargo de aquél”174, todo un logro no sólo jurídico sino también social, suscitado por la diligente jurista Mercedes Formica, quien hizo llegar a través de la ironía la necesidad de cambiar el Código Civil, conocida por ello como "la reformica". Propuso el cambio de la denominada casa del marido por un apropiado hogar conyugal, y promovió la eliminación del depósito de la mujer del art. $68.2^{\circ}$ Cc. Esta improcedente figura jurídica consistía en trasladar o depositar a la mujer que solicitaba separación o divorcio fuera de la casa del marido ${ }^{175}$ (en un convento, en casa de sus padres, etc); reflejo de la función de la mujer como un sujeto circunstancial y accesorio del hombre.

Para finalizar, la Ley confecciona un régimen de gananciales que pueda salvaguardar, en cierta medida, los intereses patrimoniales de la mujer, pues "los legítimos intereses de los cónyuges, singularmente los de la mujer, de ordinario están más expuestos a sucumbir". Con este sentido se le faculta para intervenir en el patrimonio conyugal cuando se encuentre en régimen de gananciales, mediante el llamado consentimiento uxoris $^{176}$, dispuesto en el art. $1413 \mathrm{Cc}^{177}$. Esta modificación ha sido considerada una de las más importantes del Código, ya que opera a modo de escudo ante los abusos del marido en sus intereses patrimoniales.

A partir de este momento, se exige en la sociedad de gananciales el consentimiento de la mujer casada para los actos dispositivos sobre bienes inmuebles o establecimientos

\footnotetext{
${ }^{171}$ En palabras de BATLLE VÁZQUEZ, M., op. cit., p. 12, “desigualdad tan irritante respecto al varón que aún bínubo conservaba todos sus derechos paternos ha sido borrada por la nueva letra”.

${ }^{172}$ Art. 67 Cc con la reforma de 1958: La mujer que se proponga demandar la separación o nulidad de su matrimonio puede pedir que se le separe provisionalmente de su marido y que se le confíen, con igual carácter, los hijos menores de siete años, se le señale un domicilio y si es menor de edad, la persona bajo cuya custodia haya de quedar, así como los auxilios económicos necesarios a cargo de su cónyuge, medidas que quedarán sin efecto si en los treinta días siguientes no se acreditara la interposición de la demanda o en cuanto se justifique la inadmisión de ésta.

${ }^{173}$ Art. 68 Cc con la reforma de 1958: Admitidas las demandas de nulidad o de separación de matrimonio, el Juez adoptará, durante la sustanciación del proceso, las medidas siguientes (...): 2 . Determinar cuál de los cónyuges ha de continuar en el uso de la vivienda común, teniendo en cuenta, ante todo, el interés familiar más urgentemente necesitado de protección, así como las ropas, objetos y muebles que podrá llevar consigo el cónyuge que haya de salir de aquélla.

${ }^{174}$ VILLANUEVA LUPIÓN, C., op. cit., p. 66.

${ }^{175}$ MORAGA GARCÍA, M. A., op. cit., p. 239.

176 Ídem, p. 238, también llamado consentimiento de la mujer.

177 Art. 1413 Cc, con la reforma del 1958: El marido, además de las facultades que tiene como administrador, podrá enajenar y obligar, a título oneroso, los bienes de la sociedad de gananciales; pero necesitará el consentimiento de la mujer o, en su defecto, autorización judicial a solicitud fundada del marido y del modo previsto en el párrafo siguiente, para actos de disposición sobre inmuebles o establecimientos mercantiles. Cuando el marido venga efectuando actos dispositivos sobre bienes no comprendidos en el párrafo anterior que entrañen grave riesgo para la sociedad de gananciales, podrá el Juez de Primera Instancia, a solicitud fundada de la mujer, oyendo a su consorte y previa información sumaria, adoptar aquellas medidas de aseguramiento que estime procedentes. En todo caso, no podrán perjudicar a la mujer, ni a sus herederos, los actos de disposición que el marido realice en contravención de este Código o en fraude de la mujer, sea cual fuere la condición de los bienes afectados.
} 
mercantiles ${ }^{178}$. Estas facultades se traducen en limitaciones al poder omnímodo masculino, pues pierde el monopolio en la gestión de los bienes gananciales, evitando las nefastas consecuencias que ello comportaba para la mujer.

Dicho todo esto, para un sector doctrinal ${ }^{179}$, la mujer casada "no ha sido objeto de reforma alguna en su capacidad por entenderse (...) que había de mantenerse el sistema de unidad de dirección del grupo familiar"180. Sin embargo, considero las disposiciones comentadas razón suficiente como para apreciar una modificación a favor de sus derechos que, aunque fue claramente insuficiente y mantuvo profundas discriminaciones, posiblemente fue el motor de las futuras reformas legislativas en la materia. Lamentablemente, las modificaciones que debieran realizarse para la consecución de este objetivo no podían resquebrajar los principios del ordenamiento, de manera que el sistema frustra cualquier intento o extremismo que pueda desvirtuar el papel de la mujer en el hogar y la sagrada institución de la familia ${ }^{181}$.

En mi opinión, la aspiración del legislador de 1958 no es otra que la de empoderar al sujeto débil sin pretender arrebatar poder al fuerte. Es cierto que se otorga a la esposa su esfera de autonomía, que empieza a dirigir el patrimonio conyugal, que tiene un respaldo legal si decide separarse, lo que supone un gran avance. Pero la gerencia del matrimonio sigue en manos del marido. RICOY CASAS habla de esta doble intención: “a pesar de la declaración con la que iniciaba el preámbulo -de la Ley del 1958-en pos del principio de igualdad, de nuevo se estableció una gran separación (...) entre el deber ser y el ser" ${ }^{182}$. No es necesario leer entre líneas para ver que se intentan conciliar ideales antagónicos: la liberación de la mujer y el mantenimiento del sistema cristianopatriarcal en el matrimonio.

\section{Ley de 22 de julio de 1972.}

Menos importante resulta la Ley de 22 de julio de 1972. El contexto en el que se encuadra, a todos los niveles, dista mucho de aquel de la reforma del 58. El crecimiento económico y el consumismo, la inserción de la mujer en el mundo laboral ${ }^{183}$, la apertura a Europa ${ }^{184}$ o la consolidación del sector terciario en nuestro país, introducen un sistema

\footnotetext{
${ }^{178}$ Matiza BATLLE VÁZQUEZ, M., op. cit., p. 18, que “esta protección resulta imperfecta, porque en el caso de enajenación de inmuebles y establecimientos mercantiles la intervención previa de la mujer evita el fraude, pero en la disposición de muebles no se evita”.

${ }^{179}$ BATLLE VÁZQUEZ, M., op. cit., o CASTÁN TOBEÑAS, J., op. cit., entre otros.

${ }^{180}$ BATLLE VÁZQUEZ, M., op. cit., p. 12.

${ }^{181}$ Por ser la familia “la más íntima y esencial de las comunidades, no puede originar desigualdades, pero sí ciertas diferencias orgánicas, derivada de los cometidos que en ella incumben a sus componentes, para el mejor logro de los fines morales”, preámbulo de la Ley de 24 de abril de 1958.

${ }^{182}$ RICOY CASAS, R. M., op. cit., p.314.

183 VILLANUEVA LUPIÓN, C., op. cit., p. 68, refleja como ejemplo la Ley de 22 de Julio de 1961, sobre derechos políticos, profesionales y de trabajo de la mujer, que reconoce a la mujer como trabajadora y suprime la excedencia forzosa por contraer matrimonio, entre sus conquistas, aunque para la mujer casada la licencia marital continuase siendo conditio sine qua non para trabajar.

${ }^{184}$ Ídem, pp. 68 y 69, en esta materia, es importante la Comisión de la Condición Jurídica y Social de la Mujer y la Declaración sobre la eliminación de la discriminación contra la mujer, adoptada por la ONU el 7 de Noviembre de 1967, "que hacía constar, dentro de sus 11 artículos, de que los aspectos civiles debían manifestarse con tratamiento igualitario (...) su art. $6^{\circ}$ velaba por asegurar el principio de la igualdad de condición del marido y la esposa; de que la mujer, casada o no, tuviese iguales derechos en
} 
de valores innovador y diverso a la sociedad de décadas anteriores, en el que no tienen cabida preceptos que menoscaben de forma tan evidente la dignidad y los derechos de las personas.

Por ello, la escueta Ley 31/1972, de 22 de julio, sobre modificación de los artículos 320 y 321 Cc y determinados artículos de la LEC, elimina la restricción de la mujer mayor de edad de abandonar el domicilio sin necesidad de contraer nuevas nupcias y sobre todo, introduce en el ordenamiento jurídico la idea de sustanciales reformas.

\section{IX.- MODIFICACIONES LEGALES EN LA TRANSICIÓN ESPAÑOLA: LEY DE 2 DE MAYO DE 1975}

Con la muerte del General Francisco Franco el 20 de noviembre de 1975 y la caída de la dictadura, comienza en España la época de la transición, que duraría hasta la promulgación de la Constitución tres años más tarde. El sistema trató de lidiar con la crispación político-social fruto del acontecimiento: el sector tradicional defendía la continuidad ideológica del régimen, mientras el progresista propugnaba la fundación de un nuevo ordenamiento que diese cabida a los derechos y libertades de los ciudadanos, dentro del cual tuvo gran importancia el movimiento de las mujeres ${ }^{185}$ en su lucha contra la opresión ${ }^{186}$.

Este momento histórico conmovió el sistema jurídico existente ${ }^{187}$, en especial el derecho civil en aspectos que se habían mantenido estables durante más de cuatro siglos.

Posiblemente, en la materia que nos ocupa, uno de los detonantes que permitió la consolidación del estado social y democrático de derecho fue la Ley de 2 de mayo de $1975^{188}$, sobre reforma de determinados artículos del Cc y Cco sobre la situación jurídica de la mujer casada y los derechos y deberes de los cónyuges.

Ha sido considerada la primera norma que rompe con los valores anacrónicos que se venían arrastrando durante centenarios - pues deroga instituciones vigentes desde Las Leyes de Toro, y que a su vez inspiraron el Código decimonónico-, relativos a la condición jurídica de la mujer casada, para lo que fue necesario trastocar los pilares fundamentales del derecho de familia y matrimonial.

Dispone la ley que las trabas impuestas a la mujer en el matrimonio, "si en otros tiempos pudieron tener alguna explicación, en la actualidad la han perdido", motivo por el cual urge instaurar nuevos principios más acordes a la realidad democrática que

el derecho civil; y el derecho de las mujeres en igualdad con los hombres a cambiar de nacionalidad, entre otras".

${ }^{185}$ VENTURA FRANCH, A., op. cit., p. 94, recuerda que "era difícil delimitar la lucha por los derechos de la mujer de la lucha antifranquista”.

${ }^{186}$ Para VENTURA FRANCH, A., op. cit., p. 91, "es en el año 1975 cuando el movimiento feminista aparece como tal a nivel estatal, aunque antes ya funcionaban algunos grupos (...) en la clandestinidad". ${ }^{187}$ Conviene mencionar que la renovación legislativa se produjo también en otros campos, como el penal; por ejemplo, se despenaliza el adulterio y el amancebamiento.

${ }^{188}$ Ley 14/1975, de 2 de mayo, sobre reforma de determinados artículos del Código Civil y del Código de Comercio sobre la situación jurídica de la mujer casada y los derechos y deberes de los cónyuges, publicado en el BOE el 5 de mayo de 1975. 
en el año 75 se vislumbraba.

Dentro de nuestro tema de estudio, ley cambia disposiciones relativas a:

- $\quad$ Nacionalidad. La preponderancia en nuestro ordenamiento del principio de unidad de dirección de la familia ha marcado la normativa civil. Una de sus manifestaciones ha sido el art. 22 Cc, que obligaba a la esposa a seguir a la ley personal del marido.

Quizás en las décadas anteriores a la promulgación de la Ley, la repercusión del precepto no era tal como para exigir su exclusión del Código, pero en la década de los 70, la creciente interdependencia entre los países, el progreso económico y la globalización han exigido el replanteamiento de la legislación relativa a la nacionalidad, modificando los artículos $21 \mathrm{Cc}^{189}, 22 \mathrm{Cc}^{190}, 23.3^{\circ}$ y $4^{\circ} \mathrm{Cc}^{191}$ y 25 $\mathrm{Cc}^{192}$. De esta manera, "la reforma consagra el criterio de que el matrimonio no incide por sí sólo y de manera automática en la adquisición, pérdida o recuperación de la nacionalidad española”, primando la voluntariedad a la unidad de dirección, lo que supone un avance destacable.

- $\quad$ Régimen jurídico de la capacidad de obrar de esposa. La mejora en la capacidad jurídica y de obrar de la mujer es el suceso más relevante de la Ley, en torno al cual giran el resto de modificaciones aquí expuestas. Desaparece, por fin, la licencia marital, canalizando el Código hacia el respeto de la dignidad de los cónyuges y el equilibrio en sus derechos y obligaciones. Un principio novedoso que busca instaurar en el ordenamiento la igualdad como base de las relaciones interconyugales. De eta manera, se cambian: el art. $57 \mathrm{Cc}^{193}$, por el que los

\footnotetext{
189 Art. 21 Cc con la reforma de 1975: El matrimonio por sí solo no modifica la nacionalidad de los cónyuges ni limita o condiciona su adquisición, pérdida o recuperación, por cualquiera de ellos con independencia del otro. El cónyuge español sólo perderá su nacionalidad por razones de matrimonio con persona extranjera si adquiere voluntariamente la de ésta. El cónyuge extranjero podrá adquirir la nacionalidad española por razón de matrimonio si expresamente optare por ella, con aplicación de lo dispuesto en el párrafo final del artículo 19 y en el último párrafo del artículo 20.

190 Art. 22 Cc con la reforma de 1975: Perderán la nacionalidad española los que hubieran adquirido voluntariamente otra nacionalidad. Para que la pérdida produzca efectos, se requiere tener veintiún años cumplidos, o dieciocho y hallarse emancipado; haber residido fuera de España, al menos, durante los tres años inmediatamente anteriores, $y$, en cuanto a los varones, no estar sujetos al servicio militar en período activo, salvo que medie dispensa del Gobierno. No podrá perderse la nacionalidad española por adquisición voluntaria de otra, incluso por razón de matrimonio, si España se hallare en guerra. No obstante lo dispuesto en el párrafo primero, la adquisición de la nacionalidad de un país iberoamericano o de Filipinas no producirá pérdida de la nacionalidad española cuando así se haya convenido expresamente con el Estado cuya nacionalidad se adquiere.

${ }^{191}$ Art. $23.3^{\circ}$ y $4^{\circ}$ Cc con la reforma de 1975: También perderán la nacionalidad española (...) 2. ${ }^{\circ}$ Los que por sentencia firme sean condenados a la pérdida de la nacionalidad española, conforme a lo establecido en las Leyes penales. 3. ${ }^{\circ}$ Los hijos que se encuentren bajo la patria potestad, si el que la ejerce pierde la nacionalidad española, siempre que les corresponde la que adquiera éste.

${ }^{192}$ Art. 25 Cc con la reforma de 1975: Los hijos que hayan perdido la nacionalidad española por razón de la patria potestad, una vez extinguida ésta tienen derecho a recuperarla mediante el ejercicio de la opción regulada en el artículo 18. Los que hayan sido condenados a la pérdida de la nacionalidad española o hayan sido privados de ella por haber entrado al servicio de las armas o ejercer cargo en Estado extranjero, sólo podrán recobrarla por concesión graciosa del Jefe del Estado.

193 Art. 57 Cc con la reforma de 1975: El marido y la mujer se deben respeto y protección recíprocos, y actuarán siempre en interés de la familia.
} 
cónyuges se deben proteger y respetar, borrando el conocido precepto del deber de obediencia; art. $58 \mathrm{Cc}^{194}$, conforme al cual ambos acuerdan el lugar de residencia ${ }^{195}$; art. $60 \mathrm{Cc}^{196}$, que cambia la representación del marido por la prohibición de disponer de los bienes conyugales al cónyuge menor de edad, si lo hubiese; art. $61 \mathrm{Cc}^{197}$, prohíbe de tomar dinero a préstamo, enajenar o disponer de los bienes raíces al cónyuge menor; art. $62 \mathrm{Cc}^{198}$, afirma para ambos la igualdad en su capacidad, sin ser el matrimonio una pérdida de la misma; art. $63 \mathrm{Cc}^{199}$, impide otorgarse la representación del otro cónyuge sin su consentimiento; art. $64 \mathrm{Cc}^{200}$, por el que marido y mujer, recíprocamente, disfrutan de los honores del otro; art. 65 $\mathrm{Cc}^{201}$, que establece la anulabilidad de los negocios jurídicos celebrados sin el consentimiento del cónyuge, cuando éstos lo requieran por ley; y art. $66 \mathrm{Cc}^{202}$, pueden ambos cónyuges realizar actos para atender a su familia.

A partir de entonces, el hecho de contraer matrimonio no supone -al menos formalmente- una merma de capacidad ni una limitación en sus derechos, lo que se constata a través de la renovación de los artículos: art.68.4 ${ }^{\circ} \mathrm{Cc}^{203}$, que "establece

194 Art. 58 Cc con la reforma de 1975: Los cónyuges fijarán de común acuerdo el lugar de su residencia. En su defecto, sí hubiere hijos comunes, prevalecerá la decisión de quien ejerza la patria potestad, sin perjuicio de que a instancia del otro cónyuge pueda el Juez determinar lo procedente en interés de la familia. En los demás casos, resolverán los Tribunales.

195 Aunque no desaparece el principio de unidad de dirección en el precepto, ya que en caso de desacuerdo entre los cónyuges, resuelve aquél que tenga la patria potestad, que en la fecha de la Ley aún correspondía en primer lugar al padre.

196 Art. 60 Cc con la reforma de 1975: El marido y la mujer menores de dieciocho años no podrán administrar los bienes comunes, cuando les corresponda, sin el consentimiento del otro cónyuge si fuere mayor de edad. Si éste fuere menor de edad y si se tratare de bienes privativos, el menor de dieciocho años no podrá administrar sin el consentimiento de su padre, en defecto de éste, sin el de su madre, y, a falta de ambos, sin el de su tutor.

197 Art. 61 Cc con la reforma de 1975: En ningún caso, mientras no lleguen a la mayor edad, podrán el marido o la mujer, sin el consentimiento de las personas mencionadas en el artículo anterior, tomar dinero a préstamo, gravar ni enajenar los bienes raíces.

198 Art. 62 Cc con la reforma de 1975: El matrimonio no restringe la capacidad de obrar de ninguno de los cónyuges. El casado menor de edad necesitará para comparecer en juicio, según los casos, el consentimiento de las personas mencionados en los artículos 80 y 81.

199 Art. 63 Cc con la reforma de 1975: Ninguno de los cónyuges puede atribuirse la representación del otro sin que le hubiera sido conferida voluntariamente.

200 Art. 64 Cc con la reforma de 1975: El marido y la mujer gozarán de los honores de su consorte, excepto los que fueren estricta y exclusivamente personales, y los conservarán mientras no contraigan nuevo matrimonio. En caso de separación legal no los perderá el cónyuge inocente.

201 Art. 65 Cc con la reforma de 1975: Cuando la Ley requiera para actos determinados que uno de los cónyuges actúe con el consentimiento del otro, los realizados sin él y que no hayan sido expresa o tácitamente confirmados, podrán ser anulados a instancia del cónyuge cuyo consentimiento se haya omitido o de sus herederos.

202 Art. 66 Cc con la reforma de 1975: Cualquiera de los cónyuges podrá realizar los actos relativos a cosas o servicios para atender las necesidades ordinarias de la familia, encomendadas a su cuidado, conforme al uso del lugar y las circunstancias y posición de la misma.

${ }^{203}$ Art. $68.4^{\circ}$ con la reforma de 1975: Admitidas las demandas de nulidad o de separación de matrimonio, el Juez adoptará (...) 4. ${ }^{\text {a }}$ En cuanto al régimen económico matrimonial, se seguirán las siguientes reglas: Cada uno de los cónyuges tendrá la administración y disposición de sus bienes privativos y se entenderán revocadas las facultades que uno de ellos hubiese otorgado al otro. Se mantendrá, en cuanto a los bienes dotales, el régimen anterior a la presentación de la demanda, salvo que el Juez estime conveniente transferir a la mujer la administración de los bienes de la dote inestimada. El Juez, atendidas las 
las normas relativas al régimen económico-matrimonial en la fase de tramitación del procedimiento judicial de nulidad o de separación”; art. $189 \mathrm{Cc}^{204}$, constituyendo la posibilidad de solicitar separación de bienes del cónyuge ausente; art. $224 \mathrm{Cc}^{205}$, por el que la prodigalidad no afecta al régimen jurídico del cónyuge procedente de la patria potestad o matrimonio; arts. $237.7^{\circ} \mathrm{Cc}^{206}$ que elimina la prohibición a la mujer casada para ser tutora y protutora; art. $893 \mathrm{Cc}^{207}$, también albacea; art. $995 \mathrm{Cc}^{208}$, por el que puede aceptar herencia; art. $1053 \mathrm{Cc}^{209}$, puede pedir la partición de la misma; art. $1301 \mathrm{Cc}^{210}$, se elimina la acción de nulidad de los actos de la esposa realizados sin licencia; art. $1716 \mathrm{Cc}^{211}$, suprime la prohibición de la mujer casada de ser mandataria sin licencia...; en definitiva, se ha dado una nueva redacción a todos los preceptos que incluían la autoridad marital.

He extraído del elenco de artículos uno de ellos que requiere mención aparte. La propia ley hace alusión al discutido art. $1263.3^{\circ}$ Cc con el término vejatorio, y no es para menos, pues el legislador hasta el año 1975 en la prestación del consentimiento iguala a las esposas en sus capacidades a las de las personas con deficiencias físicas o psíquicas que impiden su autogobierno. Era preciso y urgente que el Código respetase, no solo la libertad y autonomía de las mujeres, sino su dignidad como personas, borrando este tipo de preceptos y creando un nuevo sistema moral y jurídico.

- Pactos de modificación del régimen económico matrimonial. Durante décadas justifica la Ley- la voluntad de los cónyuges debía ser sacrificada por un bien superior; la protección de la mujer. Así lo expresa al decir "la regla de la inmodificabilidad partía de la idea de que, a través de los pactos posnupciales,

circunstancias del caso, determinará a cuál de los cónyuges se atribuye la administración de los bienes gananciales o de parte de ellos.

${ }^{204}$ Art. 189 Cc con la reforma de 1975: El cónyuge del ausente podrá solicitar la separación de bienes, de conformidad con lo dispuesto en el artículo 1.433 de este Código.

${ }^{205}$ Art. 224 Cc con la reforma de 1975: La declaración de prodigalidad no afecta a los derechos y deberes personales derivados del matrimonio y de la patria potestad, ni atribuye al tutor facultad alguna sobre la persona del pródigo.

${ }^{206}$ Art. $237.7^{\circ}$ Cc con la reforma de 1975: No pueden ser tutores ni protutores (...) Las mujeres casadas que no hubieren obtenido licencia de su marido.

${ }^{207}$ Art. 893 Cc con la reforma de 1975: No podrá ser albacea el que no tenga capacidad para obligarse. El menor no podrá serlo, ni aún con la autorización del padre o del tutor.

${ }^{208}$ Art. 995 Cc con la reforma de 1975: Cuando la herencia sea aceptada sin beneficio de ínventario, por persona casada y no concurra el otro cónyuge, prestando su consentimiento a la aceptación, no responderán de las deudas hereditarias los bienes de la sociedad conyugal.

209 Art. 1053 Cc con la reforma de 1975: Cualquiera de los cónyuges podrá pedir la partición de la herencia sin intervención del otro.

210 Art. 1301 Cc con la reforma de 1975: La acción de nulidad sólo durará cuatro años. Este tiempo empezará a correr: En los casos de intimidación o violencia, desde el día en que éstas hubiesen cesado. En los de error, o dolo, o falsedad de la causa, desde la consumación del contrato. Cuando la acción se refiera a los contratos celebrados por los menores o incapacitados, desde que salieren de tutela. Si la acción se dirigiese a invalidar actos o contratos realizados por uno de los cónyuges sin consentimiento del otro, cuando este consentimiento fuere necesario, desde el día de la disolución de la sociedad conyugal o del matrimonio salvo que antes hubiese tenido conocimiento suficiente de dicho acto o contrato.

${ }^{211}$ Art. 1716 Cc con la reforma de 1975: El menor emancipado puede ser mandatario pero el mandante sólo tendrá acción contra él en conformidad a lo dispuesto respecto a las obligaciones de los menores. 
pudiera uno de los cónyuges, generalmente la mujer, quedar sometido, en su perjuicio, al influjo psicológico del otro, sin llegar a manifestar su voluntad en condiciones de plena libertad", "lo que presupone que el régimen de gananciales beneficiaba en todo caso a la mujer" ${ }^{212}$. Pues bien, unas de las aspiraciones de la reforma es la de sustituir la rígida convención prematrimonial de los consortes por la toma de decisiones conjunta durante el matrimonio, en virtud de la autonomía de la voluntad. Esto se consigue ofreciendo la posibilidad a los cónyuges de otorgar capitulaciones y modificar su régimen económico matrimonial, antes y constante el matrimonio, en relación a sus bienes presentes y futuros ${ }^{213}$.

- Bienes parafernales. La reforma de los artículos relativos a los bienes parafernales $^{214}$, no deja de ser consecuencia de la mejor condición jurídica de la casada, pues al suprimir la potestad marital la mujer tiene total disponibilidad sobre estos bienes, pudiendo enajenarlos, gravarlos, hipotecarlos, etc, prohibiéndole al marido cualquier tipo de actuación sobre los mismos ${ }^{215}$, y permitiéndole actuar únicamente como apoderado.

- Administración por la mujer de los bienes conyugales durante el matrimonio. Siguiendo el argumento de la reforma de igualdad jurídica entre marido y mujer, "ha parecido procedente conferir a la mujer administradora las mismas facultades para disponer de bienes comunes", conforme al art. $1444 \mathrm{Cc}^{216}$. Asimismo, el art. $1442 \mathrm{Cc}^{217}$ "ha sido modificado con base en un criterio de reciprocidad: cuando la administración de los bienes del matrimonio recae en la mujer, ésta debe tener idénticas facultades y responsabilidad que el marido cuando es éste quien la ejerce”.

Con el cambio legislativo se logra al fin el establecimiento en el Derecho

\footnotetext{
${ }^{212}$ VILLANUEVA LUPIÓN, C., op. cit., p. 71.

213 Art. 1315 Cc con la reforma de 1975: Los que se unan en matrimonio podrán otorgar sus capitulaciones antes o después de celebrarlo, estipulando las condiciones de la sociedad conyugal relativamente a los bienes presentes y futuros, sin otras limitaciones que las señaladas en este Código. A falta de contrato sobre los bienes, se entenderá el matrimonio contraído bajo el régimen de la sociedad legal de gananciales.

Art. 1320 Cc con la reforma de 1975: os cónyuges mayores de edad podrán en todo momento, actuando de común acuerdo, modificar el régimen económico, convencional o legal, del matrimonio. Si alguno de ellos fuere menor de edad se estará a lo dispuesto en el artículo 1.318.

${ }^{214}$ Art. 1387 Cc con la reforma de 1975: La mujer puede disponer por sí sola de los bienes parafernales sin perjuicio de lo dispuesta en el artículo 61 de este Código.

Art. 1388 Cc con la reforma de 1975: La mujer podrá comparecer en juicio y litigar sobre sus bienes parafernales.

Art. 1389 Cc con la reforma de 1975: El marido a quien hubieren sido entregados bienes parafernales está sometido, en el ejercicio de su administración, a las reglas establecidas en las capitulaciones matrimoniales y, en defecto de ellas, a las del mandato contenidas en este Código

${ }^{215}$ Art. 1383 Cc con la reforma de 1975: El marido no podrá ejercitar acciones de ninguna clase respecto a los bienes parafernales, si no es como apoderado de su mujer.

${ }^{216}$ Art. 1444 Cc con la reforma de 1975: La mujer que administre los bienes del matrimonio en virtud de lo dispuesto en el artículo 1.441 tendrá las mismas facultades que al marido otorga el artículo 1.413, y necesitará la autorización judicial prevista en el mismo para actos de disposición sobre inmuebles y establecimientos mercantiles.

217 Art. 1442 Cc con la reforma de 1975: La mujer en quien recaiga la administración tendrá idénticas facultades y responsabilidad que el marido cuando la ejerce.
} 
positivo de unos ideales que se venían reivindicando desde tiempo atrás. En Europa se propugnaba desde principios del siglo XIX la autoridad de ambos cónyuges en el matrimonio -0 su equivalente, la eliminación de la licencia marital e igualdad en derechos y deberes-. "En derecho -dice FAGUET- lo que la ley debía hacer es proclamar la igualdad del hombre y de la mujer en la familia (...) aquella en que la autoridad está igualmente dividida o más bien la familia en que las autoridades están confundidas" 218 .

La ley de 2 de mayo de 1975, en suma, da un gran paso en la consecución de derechos: permite a la mujer casada alcanzar la mayoría de edad y consagra por primera vez en nuestro ordenamiento jurídico el principio de equiparación y reciprocidad entre los cónyuges.

\section{X.- BIBLIOGRAFÍA.}

AGULLÓ DÍAZ, M. C., Mujeres para Dios, para la Patria y para el Hogar. (La educación de las mujeres en los años 40). Actas del IV Coloquio de Historia de la Educación mujer y Educación en España, 1868-1975, Universidad de Santiago, Santiago de Compostela, 1990.

BARATTA, V., La situación jurídica de la mujer, esposa y madre, en la familia según las distintas legislaciones. Rivista del Notariato, Nápoles, 1953.

BATLLE VÁZQUEZ, M., “Observaciones sobre la reforma del Código Civil”, Seminario de derecho privado de Murcia, Murcia, 1958.

CASADO CANDELAS, M. J., La tutela de la mujer en Roma, Valladolid, 1972. CASTÁN TOBEÑAS, J.:

- Derecho Civil, $8^{a}$ edición, T.I, Volumen 2º Reus, Madrid, 1955.

- La condición social y jurídica de la mujer. La diferenciación de los sexos en sus aspectos biológico, sociológico, ético y jurídico, Reus, Madrid, 1955.

COSSÍO Y CORRAL, A., La potestad marital, Instituto Nacional de Estudios Jurídicos, Madrid, 1948.

DE BUEN Y LOZANO, D., Notas al Curso de Derecho civil de Colin y Capitant. T. II, volumen $1^{\circ}$, Madrid, (s.f).

DE CASTRO Y BRAVO, F.:

- Derecho Civil de España. Parte General, T.I, libro preliminar, Introducción al Derecho Civil, Madrid, 1949.

- Derecho Civil de España, T.II, Vol.1º, Madrid, 1952.

DI FEBO, G., "Nuevo Estado, nacionalcatolicismo y género", en NIELFA CRISTÓBAL, G., Mujeres y hombres en la España franquista, sociedad, economía, política y cultura, Instituto de Investigaciones Feministas-UCM, Madrid, 2003.

\footnotetext{
${ }^{218}$ FAGUET, E., Le fèminisme, París, 1910, p. 5.
} 
ESCRICHE, J., Diccionario razonado de legislación civil, penal, comercial y forense, o sea, resumen de las leyes, usos, prácticas y costumbres, como asimismo de las doctrinas de los jurisconsultos. Valencia, 1838.

FAGUET, E., Le fèminisme, París, 1910.

GACTO FERNÁNDEZ, E., "Imbecillitas sexus”, Cuadernos de Historia del Derecho, Murcia, 2013. Madrid, 1959.

GARCÍA GALLO DE DIEGO, A., Curso de Historia del Derecho Español,

GARCÍA GARRIDO, M. J., El patrimonio de la mujer casada en el derecho civil. I. Tradición romanística, Barcelona, 1982.

GETE-ALONSO Y CALERA, M. C., y SOLÉ RESINA, J., Mujer y patrimonio (el largo peregrinaje del siglo de las luces a la actualidad). Estudios monográficos, ADC, tomo LXVII, Barcelona, 2014.

GOMÁ SALCEDO, J. E., Instituciones de Derecho Común Civil y Foral, Bosch, Barcelona, 2010.

GÓMEZ LA PLAZA, C., De los bienes parafernales, Salamanca, 1976.

GÓMEZ MORÁN, L., La mujer en la historia y en la legislación, Derecho de Familia, Reus, Madrid, 1944.

GRANOTIER, P., L'autorité du mari sur la personne de la femme et la doctrine féministe, Giard et Brière, París, 1909.

HINOJOSA, E., La condición de la mujer casada en la esfera del derecho civil: Discursos leidos ante la Real Academia de Ciencias Morales y Políticas, Madrid, 1907.

IMAZ ZUBIAUR, L., "Superación de la incapacidad de la mujer casada para gestionar su propio patrimonio", en Mujeres y derecho: pasado y presente, Congreso multidisciplinar de la sección de Bizkaia de la Facultad de Derecho, Universidad del País Vasco, País Vasco, 2008.

\section{LACRUZ BERDEJO, J. L.:}

- Derecho de familia. El matrimonio y su economía, Civitas, Tratado teóricopráctico de Derecho civil, Volumen $1^{\mathrm{o}}$, Tomo IV, Barcelona, 1963.

- La potestad doméstica de la mujer casada, Zaragoza, 1963.

MADRID IZQUIERDO, J. M., El acceso de las mujeres españolas a la educación, una cuestión histórica e ideológica, Homenaje al Profesor Alfonso Capitán, Universidad de Murcia, Murcia, 2005.

MANRESA Y NAVARRO, J. M., Comentarios al Código Civil español, T.I, Revista de Legislación, Madrid, 1945.

MERCHÁN ÁLVAREZ, A., La tutela de los menores de Castilla hasta fines del siglo $X V$, Sevilla, 1976.

MOLINA PETIT, C., Dialéctica feminista de la ilustración, Barcelona, 1994. 
MORAGA GARCÍA, M. A., "Notas sobre la situación jurídica de la mujer en el Franquismo", Feminismo: revista del Centro de Estudios sobre la Mujer de la Universidad de Alicante, Alicante, 2008.

MUÑOZ GARCÍA, M. J., Limitaciones a la capacidad de obrar de la mujer casada: 1505-1975, Servicio de Publicaciones, UNEX, Cáceres, 1991.

PAJOT, G., "La mujer casada en el derecho comparado”, Revista de derecho notarial, Traducción de Ángel Blanco Soler, Madrid, 1954.

PÉREZ GONZÁLEZ, B., y CASTÁN TOBEÑAS, J., Notas a la edición española del Derecho de Familia de Theodor Kipp y Martin Wolf. $2^{\mathrm{a}}$ edición, Vol. I, Barcelona, 1979.

POTHIER, R. J., Tratado de la potestad del marido sobre la persona y bienes de la mujer, traducción de Noguera y Carles, Barcelona, (s.f.).

REY MARTÍNEZ, F., El derecho fundamental a no ser discriminado por razón de sexo, Mcgraw-Hill, Madrid, 1995.

RICOY CASAS, R. M., ¿Qué igualdad? El principio de igualdad formal y no discriminación por razón de sexo en el ordenamiento jurídico español. Colección de derechos humanos y filosofía del derecho, Dykinson, $1^{\circ}$ Edición, Volumen I, Madrid, 2010 .

ROYO MARTÍNEZ, M., Derecho de familia, Sevilla, 1949.

RUIZ FRANCO, R., ¿Eternas menores? Las mujeres en el franquismo, Biblioteca Nueva, Madrid, 2007. 1951.

SANTAMARÍA ROJAS, A., La autoridad marital en la vida, Reus, Madrid,

SCHULZ, F., Derecho Romano Clásico, Barcelona, 1960.

SENDER BEGUE, R., Luchando por la liberación de la mujer, Universidad de Valencia, Valencia, 2006.

SOLAZZI, S., La restituzione della dote in Diritto Romano, Città di Castello, Italia, 1899.

VALPUESTA FERNANDEZ, M. R., La disciplina constitucional de la familia en la experiencia europea, $1^{\text {a }}$ Edición, Tirant lo Blanch, Madrid, 2012.

VENTURA FRANCH, A., Las mujeres y la Constitución española del 1978, Instituto de la mujer, Madrid, 1999.

VILLANUEVA LUPIÓN, C., "La condición jurídica de la mujer contemporánea de Carmen de Michelena. La visión de la igualdad en el horizonte." Homenaje a Carmen de Michelena, Seminario Interdisciplinar de Estudios de Género, Universidad de Jaén, Jaén, 2014, pp. 37 a 84. 